\title{
The Costs and Benefits of Secured Creditor Control in Bankruptcy: Evidence from the UK*
}

\author{
JOHN ARMOUR, AUDREY HSU AND ADRIAN WALTERS \\ University of Oxford; National Taiwan University; Chicago-Kent College of Law
}

The theoretical literature debates whether debtors should be permitted to contract with lenders over control rights in bankruptcy. Proponents point to coordination benefits from concentrating control rights; detractors point to inter-creditor agency costs. A recent reform of UK bankruptcy law provides an opportunity to test these theories. Until 2003, UK bankruptcy law permitted firms to give complete ex post control to secured creditors, through a procedure known as "receivership." A bankruptcy reform then required firms to use a different procedure, "administration," which confers greater control on unsecured creditors. We present empirical findings from a hand-coded sample of 340 bankruptcies from both before and after the change in the law. Whilst gross realizations have increased following the change in the law, these have tended to be eaten up by increased bankruptcy costs. We infer that dispersed and concentrated creditor governance in bankruptcy may be functionally equivalent.

\section{INTRODUCTION}

The role played by secured creditors in bankruptcy proceedings has recently become prominent in policy discussions. In the US, secured creditors have been exerting a growing influence over firms in bankruptcy (Baird and Rasmussen, 2002; Skeel, 2004; Ayotte and Morrison, 2008), sparking debate over the desirability of this

\footnotetext{
* We gratefully acknowledge financial assistance from the UK Insolvency Service. We are also most grateful to Sandra Frisby for her assistance in providing access to her dataset of company failures for the purpose of identification of completed cases, and to our professional interviewees for their time and insights. We thank Douglas Baird, Bernie Black, Regis Blazy, Sandra Frisby, Meziane Lasfer, Kate Litvak, Andrew Martin, Ed Morrison, Margo Schlanger, Jay Westbrook, Ning Zhu and an anonymous referee for helpful comments and discussions on earlier drafts. This paper has benefited from comments received at presentations at the Conference on Empirical Legal Studies, University of Texas Law School, Washington University Law School, the American Law \& Economics Association Annual Meeting, two Insolvency Service Research Seminars, the Université Paris-Descartes, the Asian Law \& Economics Association Annual Meeting, a Hawksmoor Conference in London and the RIFLE workshop at Ghent University. The usual disclaimers apply.
}

DOI: $10.1515 / 1555-5879.1507$ 
development. At the same time, those formulating reform proposals for developing countries have begun to investigate the extent to which giving power to secured lenders, rather than courts, may be an effective way of overcoming limitations in judicial institutions (Safavian and Sharma, 2007; Djankov et al., 2008).

As a theoretical matter, it has been argued that secured creditor control can provide a solution to collective action problems in bankruptcy (Picker, 1992; Armour and Frisby, 2001; Gennaioli and Rossi, 2008) and that, consequently, it is desirable to permit firms to contract with their creditors over the allocation of control rights in bankruptcy (Rasmussen, 1992; Schwartz, 1998). Others, however, are strongly critical of such proposals, pointing to the possibilities for rentseeking by those in control of such a process (LoPucki, 1999; Westbrook, 2004).

Policy-makers in the UK have grappled with these issues in a recent bankruptcy reform, the results of which may have implications for these more general debates. Until recently, UK firms could opt to place control in bankruptcy proceedings in the hands of secured creditors. A creditor holding a 'floating charge' (a security interest similar to the UCC's floating lien) had the right to appoint an administrative receiver, who had plenary powers to manage the debtor firm and yet owed fiduciary duties only to the secured creditor. This receivership system was perceived to lead to excessive liquidations and inflated bankruptcy costs, because senior claimants lack incentives to maximize recoveries and minimize costs in cases where the firm's assets are worth more than the face value of the senior debt (Aghion et al., 2002). In response to these concerns, the UK's Enterprise Act 2002 shifted power from secured to unsecured creditors in bankruptcy.

We present the results of the first systematic empirical comparison of the UK's old and new bankruptcy regimes. We analyze a hand-coded sample of 340 bankruptcy cases, comprising 109 administrative receiverships commencing in 2001-2003, 195 administrations commencing in 2003 and 2004, after the change in the law, ${ }^{1}$ and a smaller sample of 36 administrative receiverships commencing in 2003 and 2004, after the change in the law. We find evidence that, as compared with administrative receivership, the new administration procedure tends to generate both higher gross asset realizations and higher direct costs, the results as to costs being the most robust. Moreover, there is no significant difference in the number of bankrupt firms that are kept open under the new regime. On this basis, it is quite plausible that any gains to creditors from increased realizations are eaten up in higher direct costs, implying a net reduction in welfare. We interpret these findings as casting doubt on strong theoretical

1 The new law came into force on 15 September 2003.

Review of Law \& Economics, (C) 2012 by De Gruyter 
claims for the superiority of one form of investor governance in bankruptcy proceedings over another.

The rest of this paper is structured as follows. Section 2 reviews prior literature, explains the structure of UK corporate bankruptcy law, and formulates hypotheses. Section 3 describes our data. Results are presented in section 4, along with robustness checks, and section 5 concludes with a discussion of the implications.

\section{LITERATURE REVIEW AND FORMULATION OF HYPOTHESES}

\subsection{THEORY}

When a firm becomes unable to pay its debts, the firm's creditors become entitled to take control of its assets. A justification for bankruptcy procedures is that collective action problems between the creditors may lead to inefficient loss of complementarities between the firm's assets (Jackson, 1986). Secured creditors have rights to payment from the sale of particular assets, as opposed to a claim against the debtor's general assets. If secured creditors' enforcement rights were not stayed in bankruptcy, then enforcement by multiple secured creditors would lead to inefficient liquidation (Webb, 1990). However, if a single security interest is granted over the entirety of the company's assets, then theory predicts that there should be no collective action problems ex post (Picker, 1992). Thus, whilst permitting multiple secured creditors to have control rights as regards individual complementary assets involves a coordination problem, permitting only a single creditor to do so against all the assets does not. ${ }^{2}$

Moreover, giving such control rights to a secured lender ex post can complement the monitoring functions that a concentrated lender can provide during the life of the loan. All-encompassing secured credit facilitates control by the secured lender, especially when combined with revolving overdraft facilities and extensive loan covenants (Scott, 1986; Franks and Sussman, 2005; Baird and Rasmussen, 2006; Armour, 2006). Thus a concentrated secured lender is in a position to assist in keeping the debtor's management under control (Triantis and Daniels, 1995; Baird and Rasmussen, 2002).

If a collective bankruptcy procedure is not mandatory, then the extent to which firms succeed in resolving creditor coordination problems will depend

2 There is hence an important ambiguity in measures of 'creditor rights,' such as that constructed by La Porta et al. (1998), which condition on whether or not secured creditors are stayed in bankruptcy without considering whether all-encompassing security interests are permitted. 
on the way their debt finance is structured. Some have argued that freedom of contract in this domain is likely to yield outcomes better tailored to the particular features of debtors than a 'one-size-fits-all' mandatory procedure (Rasmussen, 1992; Schwartz, 1998; Gennaioli and Rossi, 2008). Others predict that such a contracting process would itself suffer from coordination failures, justifying a mandatory regime (LoPucki, 1999; Westbrook, 2004).

The issue has received little empirical attention, largely owing to difficulties of comparability. A recent exception is Djankov et al. (2008), who categorize insolvency procedures around the world into 'reorganization,' involving a stay of all secured creditors, and 'foreclosure,' connoting enforcement by a single secured creditor where all-encompassing security is permitted. Using survey evidence from practitioners concerning a hypothetical case study, they conclude that there may be little to choose between these two types of procedure in terms of ex post efficiency. However, these results may be sensitive to the nature of the hypothetical employed.

\subsection{UK BANKRUPTCY LAW}

Until recently, UK bankruptcy law did not impose a stay on the enforcement of secured claims. Instead, a secured creditor holding an all-encompassing security interest-known in the UK as a 'floating charge'-was permitted to enforce against the entirety of the debtor firm's assets. The structure of firms' lending agreements, and the security interests granted, are a matter for private contracts with their creditors. The market practice in the UK was for firms to enter into a relational lending agreement with a single bank, which would be granted a package of security interests such that enforcement would give it effective control over the entirety of the debtor's assets (Armour and Frisby, 2001; Franks and Sussmann, 2005). ${ }^{3}$ In effect, the bank conducted a private liquidation, known as an 'administrative receivership' (or 'receivership' for short). Receivership would preempt enforcement by unsecured creditors, but would not stay lenders with security ranking senior to the appointing bank. In practice, UK firms would typically structure their lending so that the bank held a package including senior security as well as a floating charge. This contrasted starkly with US federal bankruptcy law, under which all secured creditors are stayed from enforcing during insolvency proceedings, ${ }^{4}$ although in recent years debtor-in-possession

\footnotetext{
3 The use of security in 'relational' lending arrangements was first posited by Scott (1986), who focused on its role in controlling financial agency costs during the life of the loan, as opposed to reducing enforcement costs ex post.

411 USC \$362. In Chapter 7, control of the bankrupt firm is transferred to a creditorappointed trustee, whereas in Chapter 11 the debtor's management usually remains in control of the firm during the proceedings.
}

Review of Law \& Economics, (C 2012 by De Gruyter 
financing agreements have been used by secured creditors to reassert control in Chapter 11 proceedings (Baird and Rasmussen, 2002; Skeel, 2004; Ayotte and Morrison, 2008).

Giving ex post control to a single secured creditor created conflicts of interest between the receiver auctioning the assets on the bank's behalf and the junior creditors (Benveniste, 1986; Aghion et al., 1992; Finch, 1999; Mokal, 2004). Where the value of the firm's assets was greater than the amount of secured debt owed, then the secured creditor was not the residual claimant and hence the receiver did not have strong incentives to maximize value. Some suggested that this tended to induce inefficient liquidation, on the assumptions that a 'fire sale' was quicker than a going concern sale, and that oversecured banks preferred to be paid as quickly as possible (Benveniste, 1986; Aghion et al., 1992). It was also suggested that oversecured banks had little incentive to monitor receivers, leading to inflated professional fees for the conduct of the receivership (Mokal, 2004). However, in cases where the value of the firm's assets was less than the amount owed to the secured creditor (that is, they were undersecured), the bank was the residual claimant and the receiver would have appropriate incentives to maximize value (Armour and Frisby, 2001; Ayotte and Morrison, 2008)..$^{5}$

Another potential limitation of the receivership system was that it resulted only in auctions of assets, rather than reorganizations of corporate entities (Insolvency Service, 2001; Mokal, 2004). Whilst going concern sales via an auction may in many cases be quicker and cheaper than reorganizations (Baird, 1986), if the economy is in a general downturn, then potential purchasers of distressed businesses (likely competitors) are themselves likely to be liquidity constrained, depressing the prices that can be achieved in an auction (Shleifer and Vishny, 1992). ${ }^{6}$

The UK's Enterprise Act 2002 introduced a package of reforms to bankruptcy law that were intended to correct the perceived problems with receivership (Insolvency Service, 2001). The entitlement of floating charge holders to appoint an administrative receiver was (with some limited exceptions) abolished. This change was prospective, applying only to floating charges created after the commencement of the legislation on 15 September 2003.

\footnotetext{
${ }^{5}$ For the incentive to be fully ameliorated, the secured creditor must be undersecured across all possible outcomes, not just expected values. That is, they may still be expected to be biased in favor of liquidation even if the expected value of continuation is less than the face value of the secured debt, where continuation has a higher variance and may in some states of the world result in recoveries going to the unsecured creditors.

6 However, the extent to which it was really necessary to provide a mechanism for reorganization as well as asset sales (whether on a going concern or piecemeal basis) was questionable, as many reorganizations are effected informally outside bankruptcy proceedings (Franks and Sussman, 2005).
} 
Instead, floating charge holders were given the right to initiate a different type of insolvency procedure, administration. This procedure, which had first been introduced in 1985, differed from receivership in that there was a stay extending to secured as well as unsecured claims, ${ }^{7}$ and that the appointee, the 'administrator,' was accountable to all the creditors.

When originally introduced in 1985, administration had been intended to serve as a substitute for receivership in cases where there was no floating charge (Cork Committee, 1982). In keeping with this 'gap-filling' status, floating charge holders had been given a veto over the appointment of an administrator. Moreover, a court order was required to commence administration. As a consequence, administration was rarely used (Insolvency Service, 2001). The Enterprise Act 2002 in effect forced holders of floating charges to use administration instead of receivership. At the same time, the requirement of a court order for appointment was abolished, meaning that the floating charge holder can now appoint an administrator as quickly as they formerly could appoint a receiver.

Two mechanisms of accountability seek to ensure that the administrator considers the interests of the creditors as a whole, rather than just those of the secured creditor. First, the administrator must put proposals to a creditors' meeting for a vote within eight to ten weeks of appointment. ${ }^{8}$ The vote is taken by the unsecured creditors, unless the administrator thinks that they will receive no recoveries, in which case secured creditors vote. ${ }^{9}$ This structure can be understood as seeking to ensure that voting power resides in the hands of the residual claimant. Of course, the correct identification of the residual claimant depends upon the administrator's evaluation of the firm's value at the commencement of formal proceedings.

The administrator's legal duties form a second mechanism of accountability. He owes duties to act in the interests of the company's creditors as a whole, to perform his functions as quickly and efficiently as possible, and is statutorily

\footnotetext{
7 This includes both fixed and floating charges, and creditors holding title retention and finance lease claims. However, they may seek permission from the court to have the moratorium lifted. The moratorium will ordinarily be lifted unless the administrator is able to offer to guarantee any shortfall in the value of the collateral and make interest payments to the secured creditor out of the estate.

${ }^{8}$ The proposals must be circulated within eight weeks, and the meeting must be held within ten weeks: UK Insolvency Act 1986, Sch B1, paras 49, 51.

9 The default position is that no meeting need be held where the administrator considers that the unsecured creditors will not share in any recoveries; in this case the administrator is required simply to act in the interests of secured creditors, and a meeting is only called if requested by a creditor or creditors owed at least 10\% of the company's total debts (UK Insolvency Act 1986 Sch B1, para 52; UK Insolvency Rules 1986, rr. 2.38, 2.40-42).
}

Review of Law \& Economics, (c) 2012 by De Gruyter 
The Costs and Benefits of Secured Creditor Control in Bankruptcy / 107

obliged to pursue a hierarchy of objectives. ${ }^{10}$ The first two of these objectives are, respectively, (i) the rescue of the company as a going concern; and (ii) the achievement of a better result for the company's (unsecured) creditors than in liquidation. As between these, he must seek to do that which will yield the highest return for the (unsecured) creditors. In effect, he is legally obliged to seek to maximize the returns for the unsecured creditors-either through a corporate reorganization (objective (i)), where possible —or failing that, through any other technique (e.g. sale of the business as a going concern, or 'work through' of existing contracts) that will yield more for the creditors than an immediate fire sale (objective (ii)). Where the administrator thinks that neither (i) nor (ii) is reasonably practicable, then he may seek instead to realize assets for the benefit of a secured creditor, provided that in so doing he does not unnecessarily harm the interests of unsecured creditors. This statutory hierarchy is, like the voting mechanisms, intended to ensure that the administrator has appropriate incentives to maximize returns ex post (Armour and Mokal, 2005).

Doubts were raised as to whether these new legal mechanisms of accountability would result in a significant improvement for unsecured creditors (Frisby, 2004; Armour and Mokal, 2005). The transfer of control to unsecured creditors is incomplete, because the floating charge holder is in most cases responsible for the selection and appointment of the administrator. Banks operate 'panels' for the selection of accountants to act as their insolvency practitioners, which imposes reputational constraints on the latter's actions: those appointees who take steps contrary to a bank's interests in the course of an appointment may expect not to be appointed again. Moreover, and perhaps more importantly, the new regime makes no provision for 'statutory super-priority' to be granted to those advancing funds to the bankrupt firm. Thus the company's existing bankers retain control of funding during administration proceedings. This makes it difficult for an administrator, even if so minded, to achieve an outcome contrary to that desired by the secured creditor.

Under both old and new laws, the remuneration and costs of the officeholder (be they administrator or receiver) are payable from the insolvent estate ahead of unsecured creditors. However, there is a difference as regards their priority status vis-à-vis secured creditors. An administrator's fees and expenses incurred in the administration rank ahead of floating, but not fixed, security interests. In contrast, a receiver's fees and expenses rank ahead of all security interests held by the person who appointed him.

\footnotetext{
10 UK Insolvency Act 1986, Sch B1, paras 3-4.
} 


\subsection{FORMULATION OF HYPOTHESES}

The change in UK law effected by the Enterprise Act 2002 may be summarized as follows: the secured creditor's control of bankruptcy proceedings is reduced, in favor of increased control granted to unsecured claimants. This transfer is effected through two new mechanisms of accountability: (i) legal duties to all the creditors; (ii) the requirement for approval by a creditors' meeting. We might expect these changes to have an impact on realizations and on costs of proceedings, and we now formulate hypotheses about the likely determinants of realizations and bankruptcy costs. To assist us in structuring our intuitions about the changes in practice, we conducted thirteen open-ended interviews with professionals involved in UK bankruptcy proceedings.

\subsubsection{Realizations}

We expect the imposition of new governance mechanisms rendering the officeholder accountable to all the creditors to result in increased recoveries, because the administrator will have stronger incentives to maximize realizations. Some of the insolvency practitioners we interviewed supported this intuition, saying that the change in the law would cause them to be more careful in thinking about how best to realize the assets, although others felt it would have little effect in practice.

Hypothesis 1: Realizations may be expected to be larger in administrations than in administrative receiverships.

We would expect any such difference to be more pronounced in cases where the value of the bankrupt firm's assets is more than the amount of secured debt. This is because, if the assets are worth less than the secured debt, then in a receivership, the secured creditor will have appropriate incentives to maximize value. ${ }^{11}$

Hypothesis 1A: The increase in realizations in administrations as compared to administrative receiverships may be most pronounced in cases where secured lenders are oversecured.

\footnotetext{
11 Only the holder of a floating charge could appoint an administrative receiver (UK Insolvency Act 1986 s 29(2)). The floating charge has a lower priority ranking than other forms of secured debt in UK corporate insolvencies (see Ferran, 2008). Thus in situations where the face value of total secured debt is more than the value of the firm's assets, the floating charge holder will be undersecured.
}

Review of Law \& Economics, () 2012 by De Gruyter 
The Costs and Benefits of Secured Creditor Control in Bankruptcy / 109

\subsubsection{Costs}

The literature typically divides the costs of bankruptcy into 'direct' and 'indirect' components. Direct costs are those involved in running a bankruptcy procedure: that is, fees paid to professionals such as lawyers, accountants, valuers, business consultants and marketing experts who are employed in realizing the assets of the bankrupt firm and agreeing on an appropriate distribution of the proceeds. Such costs are relatively easy to observe, as most bankruptcy systems require that a record of such payments be kept.

Direct bankruptcy costs have been studied empirically in various jurisdictions. They are typically reported as a ratio of total firm value, in order to control for firm size. Possible denominators for comparison include the value of the pre-bankruptcy assets (either at book or estimated market value, if available) and the market value of post-bankruptcy assets, as realized by sales (which can be presented either as a gross figure or net of the associated costs of sale). The results of prior studies using samples of private firms, between them encompassing a variety of bankruptcy regimes, are summarized in Table $1 .{ }^{12}$

\section{Table 1: Prior Literature on the Direct Costs of Bankruptcy in Private Firms}

\begin{tabular}{|c|c|c|c|c|c|c|}
\hline \multirow[t]{2}{*}{$\begin{array}{l}\text { Authors } \\
\text { (year) }\end{array}$} & \multirow{2}{*}{$\begin{array}{l}\text { Jurisdiction: } \\
\text { firm type(s), } \\
\text { procedure }\end{array}$} & \multirow[t]{2}{*}{$\bar{n}$} & \multicolumn{2}{|c|}{$\begin{array}{l}\text { Mean costs, } \% \text { of } \\
\text { starting values (median) }\end{array}$} & \multicolumn{2}{|c|}{$\begin{array}{l}\text { Mean costs, } \% \text { of } \\
\text { final values (median) }\end{array}$} \\
\hline & & & \begin{tabular}{|l} 
Book \\
value
\end{tabular} & $\begin{array}{l}\text { Market value } \\
\text { (est.) }\end{array}$ & $\begin{array}{l}\text { Gross mkt } \\
\text { value }\end{array}$ & $\begin{array}{l}\text { Net mkt } \\
\text { value }\end{array}$ \\
\hline $\begin{array}{l}\text { Lawless and } \\
\text { Ferris (1997) }\end{array}$ & US: private firms, Ch 7 & 98 & & $6.1(1.1)$ & & $13.5(2.1)$ \\
\hline $\begin{array}{l}\text { Lawless and } \\
\text { Ferris (2000) }\end{array}$ & US: private firms, Ch 11 & 118 & & $17.6(3.5)$ & & $7.6(4.7)$ \\
\hline $\begin{array}{l}\text { Bris et al. } \\
(2006)\end{array}$ & $\begin{array}{l}\text { US: private firms, Ch } 7 \\
\text { US: private firms, Ch } 11\end{array}$ & \begin{tabular}{|l|}
57 \\
38 \\
222 \\
157 \\
\end{tabular} & & $\begin{array}{l}8.1(2.5) \\
16.9(1.9)\end{array}$ & $\begin{array}{l}37.9(9.6) \\
9.4(3.5) \\
\end{array}$ & \\
\hline \begin{tabular}{|l|} 
Thorburn \\
$(2000)$
\end{tabular} & $\begin{array}{l}\text { Sweden: public and private } \\
\text { firms, auction }\end{array}$ & 263 & $6.4(4.5)$ & & $19.1(13.2)$ & \\
\hline $\begin{array}{l}\text { Franks and } \\
\text { Sussman } \\
(2000)\end{array}$ & $\begin{array}{l}\text { UK: private firms, receivership } \\
\text { UK: private firms, administration }\end{array}$ & $\begin{array}{l}41 \\
7\end{array}$ & & & & $\begin{array}{l}25.2 \\
26.3\end{array}$ \\
\hline $\begin{array}{l}\text { Citron et al. } \\
(2004)\end{array}$ & UK: MBO firms, receivership & 65 & & & $15.2(14.6)$ & $24.5(21.3)$ \\
\hline
\end{tabular}

12 Lubben (2008) reports findings from a large random sample of 945 Chapter 11 reorganizations, mainly private firms. The mean level of professional fees (excluding one outlier case) is $4.0 \%$ of pre-bankruptcy assets (measured by market value) plus debts at the start of the proceedings. The results are not given simply as a proportion of pre-bankruptcy assets, and hence the findings are not directly comparable with other prior studies. 
Results reported in Franks and Sussman (2000) and Citron et al. (2004) suggest that the mean costs of insolvency practitioner remuneration in a typical UK receivership were in the region of $25 \%$ of the value of the post-bankruptcy assets, net of the costs of realization. ${ }^{13}$ Other studies report costs as a fraction of gross post-bankruptcy asset values. This tends to reduce the percentage reported. Thus Citron et al. (2004) report a mean (median) cost of $15.2 \%(14.6 \%)$ of gross post-bankruptcy assets for a sample of $65 \mathrm{MBO}$ firms (that is, firms which had previously undergone a management buyout) that subsequently went into receivership. This is similar to the figures reported by Thorburn (2000) for the Swedish bankruptcy process, in which firms are mandatorily auctioned within a year (mean 19.1\%, median 13.2\%). ${ }^{14}$

A number of studies report that the duration of insolvency proceedings (Thorburn, 2000; Franks and Sussman, 2005; Bris et al., 2006; Lubben, 2008) and the size of the debtor firm (Lawless and Ferris, 2000; LoPucki and Doherty, 2004; Bris et al., 2006; Lubben, 2008) are significant determinants of direct costs. The longer the proceedings take to complete, the greater the professional fees likely to be involved, and the greater the value of the assets at stake, the more effort is likely to be required to assess and market them.

Indirect costs of bankruptcy are those not actually paid out as expenses in the proceedings. Ex post, they include costs of decisional error by the trustee realizing the assets- that is, the costs of failing to allocate the distressed firm's assets to their highest-valued use. They also include costs resulting from unnecessary delay in the proceedings, which impacts negatively on the value of the firm's goodwill. The duration of the proceedings is therefore a possible proxy for ex post indirect costs (Bris et al., 2006).

Indirect costs are also thought to have ex ante components. These include the incentive effects of bankruptcy on management's investment strategy (Schwartz, 1994) and on the credibility of the creditor's threat to enforce (Hart, 1995). Because these affect all firms - as opposed to simply those which enter bankruptcy proceedings-they are potentially much greater in aggregate than the ex post components (White, 1996). However, it is difficult to measure ex ante costs.

\footnotetext{
${ }^{13}$ Franks and Sussman (2000) also report mean costs for a sample of seven pre-Enterprise Act administrations, which were slightly higher, at $26.3 \%$. However, the sample size is so small that little significance can be attached to this finding.

14 These costs seem somewhat higher than those reported by Lawless and Ferris (2000) and Bris et al. (2006) for Chapter 11 proceedings in the US. However, it is likely that this is because the salary of managers of firms in Chapter 11 is reported as an operating expense as opposed to a 'bankruptcy' cost, meaning that procedures in which the firm is managed by an outside appointee may be expected to generate higher reported direct costs. This conjecture is supported by results from Lawless and Ferris (1997) and Bris et al. (2006) suggesting that US Chapter 7 proceedings have significantly higher direct costs than Chapter 11.
}

Review of Law \& Economics, (C) 2012 by De Gruyter 
The Costs and Benefits of Secured Creditor Control in Bankruptcy / 111

We now formulate hypotheses regarding direct costs. Administration involves a greater likelihood of court appearances than receivership. Moreover, the administrator will be required to engage in several types of 'accountability' related actions that would not be necessitated under receivership: preparing and circulating reports to creditors; calling and conducting creditors' meetings; preparing reasons for their actions, etc. All of these may be expected to lead to increased costs as compared with receivership (Frisby, 2004; Armour and Mokal, 2005).

At the same time, if it was the case that lack of control by (over)secured creditors tended to lead to needlessly inflated costs in receivership, then it might be expected that administration, with enhanced mechanisms of accountability to unsecured creditors, would reduce these costs (Mokal, 2004). A contrary view might be that unsecured creditors are typically likely to be dispersed and so suffer from free-rider problems in exercising control over insolvency practitioners. This might lead them to have difficulty in operationalizing their new mechanisms of accountability (creditors' meetings and lawsuits against insolvency practitioners). In contrast to the problems with concentrated creditor control, which occur only when the lender is oversecured, the problems of dispersed creditor governance would manifest themselves in all cases. When combined with increased process costs, therefore, the outcome-ironically - might be expected to be increased costs as a result of the shift to the new regime.

Interviewees to whom we spoke helped clarify these intuitions. They reported that there were real process costs involved in conducting a creditors' meeting and preparing a 'paper trail' to guard against legal liability. Moreover, interviewees from banks suggested that they typically negotiated a 'bulk' rate with insolvency practitioners regarding fee arrangements, a view affirmed by a subsequent investigation into insolvency practitioners' fees by the UK's Office of Fair Trading (OFT, 2010). In contrast, when fees are put to creditors' meetings for approval, the unsecured creditors are offered a higher rate, which is accepted because the unsecured creditors are disinterested in the process. The foregoing points lead us to formulate the following hypothesis:

Hypothesis 2: Direct costs are likely to be larger in administration than in administrative receivership.

\subsubsection{Other Outcomes}

The difference between administration and administrative receivership may also be expected to have several other effects on outcomes.

Duration of proceedings (indirect costs). Administration proceedings are limited to one year, although this may be extended with the permission of the court or of 
a majority of the creditors. ${ }^{15}$ Receivership proceedings, although commonly thought to be 'quick,' are not subject to any legal time limit. Citron et al. (2004) found that, in a sample of 65 receiverships, only 3.1\% were completed within one year and 37\% took more than 3 years. We might therefore predict that administration proceedings are likely to take less time than receiverships. To the extent that duration of proceedings is a proxy for indirect costs, this also implies reduced indirect costs (Bris et al., 2006).

Asset deployment. An oversecured senior lender may be expected to have a bias in favor of liquidation fire sales, as against continuation of the business, on the basis that the former may be quicker and less risky. Consistently with this, Ayotte and Morrison (2008) report that in a sample of Chapter 11 proceedings in the US, asset fire sales are more likely in cases where the secured lenders are oversecured. Consequently, if the perverse incentive problem has been resolved by the new mechanisms of governance in administration, then we would expect to see more going concern sales, and more trading activity, in administration.

Creditor recoveries. Hypothesis 1 predicts that gross recoveries are likely to be larger in administration than in administrative receivership. Hypothesis 2 predicts that costs will, however, also increase. It is difficult to predict a priori how these two predicted changes might interact to affect net recoveries for creditors, which are the value of recoveries minus costs.

\section{DATA AND SUMMARY STATISTICS}

We study data on asset realizations and costs incurred in UK bankruptcy proceedings before and after the changes introduced by the Enterprise Act 2002, which came into force on 15 September 2003. We use a handconstructed dataset of 340 formal insolvencies to compare receiverships under the old law with administrations under the new law. This is larger than most datasets of bankruptcy costs that have been studied in the US. ${ }^{16}$

A random sample of 500 cases, comprising 250 receiverships commencing between 1 January 2001 and 14 September 2003 and 250 administrations commencing between 15 September 2003 and 31 December 2004, ${ }^{17}$ were first identified using the index of insolvency appointments published in the London Gazette. Data relating to each case were then entered manually from reports filed at the UK public register of companies, Companies House, by insolvency

\footnotetext{
15 UK Insolvency Act 1986 Sch B1, para 76.

${ }^{16}$ See above, text to notes 12-14. The exception is Lubben (2008), who studies over 1000 cases (random sample of 945 plus non-random sample of 81 cases).

17 The corporate bankruptcy provisions of the Enterprise Act 2002 came into force on 15 September 2003.
}

Review of Law \& Economics, (C 2012 by De Gruyter 
The Costs and Benefits of Secured Creditor Control in Bankruptcy / 113

practitioners. ${ }^{18}$ From the Statement of Affairs form, which must be filed shortly after the practitioner's appointment, we extracted the book value of assets, the directors' estimate of the market value of the company's assets, and the amount of creditors' claims, all as of the beginning of proceedings. Insolvency practitioners are also required to file progress reports as the proceedings continue and final statements of receipts and payments on completion of a case. From these, we collect information on the duration of the bankruptcy procedure, the realization value of the firm's assets (that is, their post-bankruptcy market value), the total remuneration paid to the insolvency practitioner and other bankruptcy-related direct costs, and distributions made to creditors. We exclude cases for which the bankruptcy procedure was not completed by 1 February 2006, and cases for which the relevant abstracts of receipts and payments were not available in electronic form via the Companies House Direct service. ${ }^{19}$ This yielded a sample of 109 preEnterprise Act receiverships and 195 administrations, as shown in Table 2.

To explore the pattern of realizations and insolvency costs across different firm characteristics, further information about the firm's SIC industry code and accounting data was obtained from the FAME database. ${ }^{20}$ Panel $\mathrm{C}$ reports the distribution of the sample firms by industry at the 1-digit SIC code level. Approximately $45 \%$ of the sample in the two respective proceedings is comprised of firms in the construction industry and in wholesale or retail trading. However, the overall industry composition of the two subsamples are similar.

For the purposes of robustness checks (detailed in section 4.3), we also gathered an additional random sample of post-Enterprise Act receivershipsthat is, receiverships commencing after 15 September 2003 and before 31 December 2004, using powers 'grandfathered' under floating charges created before the Enterprise Act came into force (see section 2.2 above). After excluding cases where data were not available for variables of interest, this yielded a modest sample of 36 post-Enterprise Act receiverships.

Table 3 presents descriptive statistics on various characteristics of sample firms. Panel A reports pre-bankruptcy characteristics of our sample firms. This shows the dataset is comprised primarily of small firms, with the most recent annual accounts showing a turnover of less than $f 4 \mathrm{~m}$ and book value of assets of less than $f 3.5 \mathrm{~m}$. These are also relatively young firms, with a mean age of less than 20 years, and a median nearer 10 . As may be expected, there is a stark decline

\footnotetext{
${ }^{18}$ For details of the forms that must be completed by Insolvency Practitioners running a case, see Companies House (2005), chs 3-4.

${ }^{19}$ See www.direct.companieshouse.gov.uk.

20 The FAME (Financial Analysis Made Easy) database provides detailed company accounting and financial information on UK and Irish public and private firms.
} 
Table 2: Panel A - Sample Collection, Panel B - The Year in which Each Sample Case Entered Insolvency Proceeding, Panel C - Industry Distributions (industry classifications based on 1-digit SIC code)

\begin{tabular}{|c|c|c|c|c|}
\hline \multirow{2}{*}{\multicolumn{2}{|c|}{ PANEL A: Data collection }} & \multicolumn{3}{|c|}{ Firm-year observations } \\
\hline & & $\begin{array}{l}\text { Pre-Act } \\
\text { receivership }\end{array}$ & Administration & $\begin{array}{l}\text { Post-Act } \\
\text { receivership }\end{array}$ \\
\hline \multicolumn{2}{|c|}{$\begin{array}{l}\text { A random sample of } 250 \text { receiverships (pre-Act) } \\
\text { commencing between } 1 \text { Jan. } 2001 \text { and } 14 \text { Sept. } 2003 \\
\text { and } 250 \text { administrations commencing between } 15 \text { Sept. } \\
2003 \text { and } 31 \text { Dec. 2004, were first identified using the } \\
\text { index of insolvency appointments published in the } \\
\text { London Gazette. For robustness tests, we also randomly } \\
\text { selected } 50 \text { post-Act receiverships commencing between } \\
15 \text { Sept. } 2003 \text { and } 31 \text { Dec. } 2004 \text {. }\end{array}$} & 250 & 250 & 50 \\
\hline \multirow{2}{*}{\multicolumn{2}{|c|}{$\begin{array}{l}\text { Less: We exclude cases in which the insolvency procedure } \\
\text { had not been completed by Feb. } 2006 \text { and cases for which } \\
\text { the Receiver's Abstract of Receipts and Payments or the } \\
\text { Administrator's Progress Report were unavailable on the } \\
\text { Companies House (www.direct.companieshouse.gov.uk) } \\
\text { website. We also exclude firm-year observations for which } \\
\text { the industry information and firm-year characteristics from } \\
\text { FAME (see fn 20) are missing. }\end{array}$}} & (141) & (55) & (14) \\
\hline & & 109 & 195 & 36 \\
\hline \multicolumn{5}{|c|}{ PANEL B: Sample distribution by year and procedure types } \\
\hline & \multicolumn{4}{|c|}{ Firm-year observations } \\
\hline year & Whole sample & $\begin{array}{l}\text { Pre-Act } \\
\text { receivership }\end{array}$ & Administration & $\begin{array}{l}\text { Post-Act } \\
\text { receivership }\end{array}$ \\
\hline 2001 & 16 & 16 & & \\
\hline 2002 & 54 & 54 & & \\
\hline 2003 & 88 & 39 & 42 & 7 \\
\hline \multirow{2}{*}{2004} & 182 & & 153 & 29 \\
\hline & 340 & 109 & 195 & 36 \\
\hline \multicolumn{5}{|l|}{ PANEL C: Sample distribution by industry } \\
\hline \multicolumn{5}{|c|}{ Firm-year observations } \\
\hline Industrial Group & Whole sample & $\begin{array}{l}\text { Pre-Act } \\
\text { receivership }\end{array}$ & Administration & $\begin{array}{l}\text { Post-Act } \\
\text { receivership }\end{array}$ \\
\hline Agriculture, forestry and fishing (1) & 1 & 0 & 1 & 0 \\
\hline Mining (2) & 19 & 8 & 10 & 1 \\
\hline Construction (3) & 79 & 28 & 42 & 9 \\
\hline Manufacturing (4) & 38 & 12 & 23 & 3 \\
\hline $\begin{array}{l}\text { Transportation, communication, } \\
\text { electric, gas and sanitary services (5) }\end{array}$ & 31 & 6 & 24 & 1 \\
\hline Wholesale / retail trade $(6)$ & 82 & 28 & 48 & 6 \\
\hline Service (7) & 90 & 27 & 47 & 16 \\
\hline Total & 340 & 109 & 195 & 36 \\
\hline
\end{tabular}

Review of Law \& Economics, (C 2012 by De Gruyter 
The Costs and Benefits of Secured Creditor Control in Bankruptcy / 115

between book values shown in the last annual accounts and estimated market values on entry into insolvency proceedings. The firms in our sample are heavily overindebted on entry. For the mean firm undergoing either insolvency procedure, the secured creditors are oversecured, in the sense that the estimated market value of the firm's assets is significantly more than the face value of the debt owed to secured creditors. However, for the median firm in administration or pre-Enterprise Act receivership, the secured lenders are undersecured. There is one statistically significant difference in means, which concerns the proportion of total debt that is secured. This is higher for pre-Enterprise Act receivership (mean 0.424 , median 0.402) than for administration (mean 0.261, median 0.228), and higher still in the post-Act receivership sample (mean 0.569, median 0.618).

Panel B reports summary statistics on characteristics of our sample cases of bankruptcy proceedings.

Table 3: Summary Statistics

\begin{tabular}{|c|c|c|c|c|c|c|c|}
\hline \multicolumn{7}{|c|}{ PANEL A: Pre-bankruptcy firm characteristics } & \multirow[b]{2}{*}{$\begin{array}{l}\text { T test for mean } \\
\text { (median) } \\
\text { relative to } \\
\text { post-Act } \\
\text { receivership }\end{array}$} \\
\hline Variables & Mean & STD & $25 \%$ & $50 \%$ & $75 \%$ & $\begin{array}{l}\text { T test for mean } \\
\text { (median) } \\
\text { relative to } \\
\text { administration }\end{array}$ & \\
\hline \multicolumn{8}{|l|}{ Age } \\
\hline Pre-Act Receivership & 16.698 & 15.426 & 6.219 & 9.958 & 22.150 & $-0.28(-0.38)$ & $1.50\left(2.07^{* *}\right)$ \\
\hline Post-Act Receivership & 12.564 & 12.941 & 3.694 & 8.169 & 16.194 & $-1.95^{*}\left(-2.43^{* *}\right)$ & \\
\hline Administration & 17.242 & 16.808 & 6.292 & 11.603 & 21.664 & & \\
\hline \multicolumn{8}{|l|}{ Turnover } \\
\hline Pre-Act Receivership & $3,841.757$ & $6,898.348$ & 0.000 & $1,738.000$ & 4,489 & $0.60\left(2.58^{* *}\right)$ & $1.27(1.45)$ \\
\hline Post-Act Receivership & $2,249.861$ & $5,345.048$ & 0.000 & 173.500 & 3,184 & $-0.87(0.15)$ & \\
\hline Administration & $3,224.682$ & $9,433.749$ & 0.000 & 0.000 & 1,932 & & \\
\hline \multicolumn{8}{|c|}{ Book value of assets $(B V)$} \\
\hline Pre-Act Receivership & $1,530,000$ & $1,880,000$ & 351,000 & 907,000 & $1,690,000$ & $-0.68\left(3.28^{* * *}\right)$ & $1.61\left(1.65^{\star}\right)$ \\
\hline Post-Act Receivership & $1,070,000$ & $1,250,000$ & 208,000 & 552,000 & $1,640,000$ & $-1.16(0.33)$ & \\
\hline Administration & $3,320,000$ & $26,900,000$ & 179,000 & 461,000 & $1,320,000$ & & \\
\hline \multicolumn{8}{|c|}{ Estimated market value of assets at entry to bankruptcy } \\
\hline Pre-Act Receivership & 805,000 & $1,220,000$ & 200,000 & 439,000 & 911,000 & $0.89\left(4.21^{* \star *}\right)$ & $0.88\left(2.02^{* *}\right)$ \\
\hline Post-Act Receivership & 632,000 & 998,000 & 135,000 & 289,000 & 421,000 & $-0.12(1.07)$ & \\
\hline Administration & 656,000 & $1,510,000$ & 69,633 & 190,000 & 572,000 & & \\
\hline \multicolumn{8}{|c|}{ Debt ratio based on estimated market value } \\
\hline Pre-Act Receivership & 8.576 & 24.219 & 1.715 & 2.799 & 6.311 & $-0.90(-0.48)$ & $-0.93(-0.09)$ \\
\hline Post-Act Receivership & 40.719 & 215.225 & 1.944 & 2.930 & 6.226 & $0.76\left(-1.56^{*}\right)$ & \\
\hline Administration & 14.330 & 64.995 & 1.849 & 3.420 & 6.424 & & \\
\hline \multicolumn{8}{|c|}{ Secured debt to total debts } \\
\hline Pre-Act Receivership & 0.424 & 0.237 & 0.237 & 0.402 & 0.571 & $5.68^{* * *}\left(5.87^{* * *}\right)$ & $-2.75^{\star *}\left(-2.55^{\star *}\right)$ \\
\hline Post-Act Receivership & 0.569 & 0.297 & 0.341 & 0.618 & 0.862 & $6.07^{* * *}\left(5.63^{* * *}\right)$ & \\
\hline Administration & 0.261 & 0.243 & 0.043 & 0.228 & 0.406 & & \\
\hline \multicolumn{8}{|c|}{ Secured debt to Assets (est. market value) } \\
\hline Pre-Act Receivership & 2.689 & 5.151 & 0.636 & 0.938 & 2.488 & $-0.54\left(4.94^{* * *}\right)$ & $-1.06(-1.23)$ \\
\hline Post-Act Receivership & 36.087 & 196.527 & 0.842 & 1.162 & 3.500 & $1.02\left(4.26^{* * *}\right)$ & \\
\hline Administration & 3.951 & 24.112 & 0.175 & 0.600 & 1.363 & & \\
\hline
\end{tabular}




\begin{tabular}{|c|c|c|c|c|c|c|c|}
\hline \multicolumn{8}{|c|}{ PANEL B: Firm characteristics during bankruptcy proceedings } \\
\hline Variables & Mean & STD & $25 \%$ & $50 \%$ & $75 \%$ & $\begin{array}{l}\text { mean (median) } \\
\text { relative to } \\
\text { administration }\end{array}$ & $\begin{array}{l}\text { mean (median) } \\
\text { relative to Post- } \\
\text { Act receivership }\end{array}$ \\
\hline \multicolumn{8}{|l|}{ Duration (days) } \\
\hline Pre-Act Receivership & 626.577 & 246.965 & 458.000 & 602.000 & 761.000 & \multirow{3}{*}{$\begin{array}{r}13.79^{* * *}\left(10.55^{* * *}\right) \\
2.24^{* *}\left(1.56^{*}\right)\end{array}$} & \multirow[t]{3}{*}{$5.67^{* *}\left(5.88^{* * *}\right)$} \\
\hline Post-Act Receivership & 393.487 & 115.062 & 310.000 & 413.000 & 500.000 & & \\
\hline Administration & 356.815 & 88.235 & 339.000 & 358.000 & 365.000 & & \\
\hline \multicolumn{8}{|c|}{ Total realizations (R1), scaled by estimated market value of assets at entry } \\
\hline Pre-Act Receivership & 1.025 & 1.280 & 0.388 & 0.746 & 1.092 & $-0.45\left(-1.98^{*}\right)$ & \multirow[t]{3}{*}{$-0.54\left(-1.77^{* *}\right)$} \\
\hline Post-Act Receivership & 1.157 & 1.328 & 0.604 & 1.006 & 1.226 & $0.29(0.86)$ & \\
\hline Administration & 1.093 & 1.240 & 0.560 & 0.877 & 1.117 & & \\
\hline \multicolumn{7}{|c|}{ Total realizations plus net trading surplus (R2), scaled by estimated market value of assets at entry } & \multirow{4}{*}{$-0.49\left(-1.87^{*}\right)$} \\
\hline Pre-Act Receivership & 1.028 & 1.379 & 0.388 & 0.705 & 1.092 & $-0.68\left(-2.71^{* *}\right)$ & \\
\hline Post-Act Receivership & 1.151 & 1.325 & 0.604 & 1.006 & 1.222 & $0.06(0.43)$ & \\
\hline Administration & 1.137 & 1.255 & 0.590 & 0.925 & 1.161 & & \\
\hline \multicolumn{8}{|c|}{ Remuneration, scaled by estimated market value of assets at entry } \\
\hline Pre-Act Receivership & 0.197 & 0.252 & 0.055 & 0.114 & 0.198 & $-3.39^{* *}(-4.05 *)$ & \multirow[t]{3}{*}{$0.88(-0.19)$} \\
\hline Post-Act Receivership & 0.167 & 0.147 & 0.054 & 0.127 & 0.268 & $-4.07^{*}\left(-2.47^{*}\right)$ & \\
\hline Administration & 0.346 & 0.513 & 0.091 & 0.194 & 0.364 & & \\
\hline \multicolumn{8}{|c|}{ Total direct costs, scaled by estimated market value of assets at entry } \\
\hline Pre-Act Receivership & 0.314 & 0.356 & 0.102 & 0.178 & 0.362 & $-3.93^{* *}\left(-4.59^{*}\right)$ & \multirow[t]{3}{*}{$0.750(-0.44)$} \\
\hline Post-Act Receivership & 0.276 & 0.227 & 0.105 & 0.228 & 0.385 & $-4.39^{* *}\left(-2.63^{* *}\right)$ & \\
\hline Administration & 0.564 & 0.748 & 0.179 & 0.347 & 0.589 & & \\
\hline \multicolumn{8}{|l|}{ Recovery rate } \\
\hline Pre-Act Receivership & 0.205 & 0.223 & 0.032 & 0.117 & 0.326 & $-0.11(-0.60)$ & \multirow[t]{3}{*}{$-2.57\left(-2.85^{* *}\right)$} \\
\hline Post-Act Receivership & 0.318 & 0.243 & 0.147 & 0.241 & 0.448 & $2.69^{* *}\left(3.26^{* * *}\right)$ & \\
\hline Administration & 0.202 & 0.237 & 0.032 & 0.112 & 0.282 & & \\
\hline Proportion of trade & & Mean & & & & & \\
\hline Pre-Act Receivership & & $9(38 / 109)$ & & & & & \\
\hline Post-Act Receivership & & $94(7 / 36)$ & & & & & \\
\hline Administration & & $7(54 / 195)$ & & & & & \\
\hline \multicolumn{8}{|c|}{ Proportion of going concern sales } \\
\hline Pre-Act Receivership & & (U大) & & & & & \\
\hline Post-Act Receivership & & $67(24 / 36)$ & & & & & \\
\hline Administration & 0.4 & $5(81 / 195)$ & & & & & \\
\hline
\end{tabular}

This table reports pre-bankruptcy firm characteristics (Panel A) and firm characteristics during bankruptcy proceedings (Panel B). Pre-Act receivership cases commence between 1 January 2001 and 14 September 2003, and Post-Act receivership and administration cases commence between 15 September 2003 and 31 December 2004. Both remuneration fees and direct costs are obtained from the 'receiver's abstract of receipts and payments' (for receiverships) and the 'administrator's progress report' (for administrations). Direct costs comprises remuneration costs, legal fees, estate agent fees, document fees, etc. Recovery rate is the net difference between asset realizations plus net trading sales, and total direct costs divided by total claims. Proportion of trade is the proportion of cases under a given procedure in which the firm continues trading during insolvency proceedings. Proportion of going concern sales is the number of cases resulting in a going concern sale relative to all cases in that legal proceeding.

Review of Law \& Economics, ( 2012 by De Gruyter 
The Costs and Benefits of Secured Creditor Control in Bankruptcy / 117

\subsection{DURATION}

The average duration of proceedings for pre-Act receivership (mean 627 days, median 602 days) was nearly twice as long as for administration (mean 357 days, median 358 days) and even for post-Act receivership (mean 393 days, median 413 days). This is consistent with our expectations: administration proceedings are subject to a statutory time limit of one year (extendable with the consent of the court or of creditors), whereas receivership has no fixed time limit. ${ }^{21}$ However, interviewees told us that in practice, most of the activity in receiverships took place in the initial stages, but that there might be a long inactive period before the procedure was formally closed. Consequently we are cautious of reading much into the difference in formal length of the procedures.

\subsection{REALIZATIONS}

Insolvency practitioners in receivership and administration cases are required to submit to the Registrar of Companies, at six-month intervals, a 'Receiver's Abstract of Receipts and Payments' or an 'Administrator's Progress Report,' respectively. These are cash-flow statements. When capital assets are sold during the reporting period, the gross realizations from asset sales must be entered as receipts and related costs entered as payments. We classify the receipt items as asset realizations. Our first measure of realizations, REA1, comprises the gross sum of payments received by the office-holder following capital asset sales.22 This gives an indication of the price obtained by the insolvency practitioner for the sale of business assets. We classify the costs specifically associated with these realizations (that is, legal fees, investigation fees, advertisement fees, and appraisal fees) as direct insolvency costs.

In cases where the insolvency practitioner continues to operate the business as a going concern, receipts and payments associated with such trading are entered into the cash flow statement-that is, sums received for goods and services, and payments made for associated costs. To ignore such trading activity might bias downward measures of realizations in cases where trading continues for some time. Consequently, we introduce a second measure of realizations, $R E A 2$, which includes such trading receipts. ${ }^{23}$ However, it would

\footnotetext{
${ }^{21}$ See above, note 15 , and text thereto.

22 During the study period, interest rates were consistently low, and we consequently do not explicitly take into account the time value of money where asset sales occur at different points in time. In our data, receiverships are on average longer than administrations. Consequently, any bias introduced by ignoring the time value of money will tend to overstate realizations in receivership relative to administrations, and thereby make it easier for our hypotheses regarding realizations to be falsified.

23 To help distinguish sums received and paid in the course of trading from asset realizations and associated costs, administrators typically provide a separate trading receipts and payments
} 
be inappropriate to treat operating costs as part of the costs of the insolvency procedure. Consequently, REA2 includes only the net receipts from tradingthat is, minus operating costs. ${ }^{24}$ We perform all of our analyses using both measures of realizations to ensure robustness:

REA1: total asset realizations,

REA2: total asset realizations + net trading receipts.

Simply comparing realizations, of course, would not give a meaningful comparison between procedures unless those figures can be standardized by a measure of firm size. Consistently with prior literature (LoPucki and Doherty, 2004; Bris et al., 2006), we use the estimated value of the firm's assets at entry into bankruptcy as an indicator of size. The value is extracted from the Statement of Affairs prepared by directors shortly after an insolvency practitioner is appointed. The directors are required to provide an abbreviated balance sheet containing their best estimate of the current value of the firm's assets and liabilities as of the commencement of bankruptcy proceedings. We winsorize these data at the $1 \%$ and $99 \%$ level. Panel B of Table 3 reports summary statistics for these two measures. The ratio of the value of actual realizations in bankruptcy to the estimated pre-bankruptcy value of the firm's assets yields one measure of the 'effectiveness' of the insolvency practitioner in realizing assets. To be sure, the directors' estimates are not audited, and may well be subject to an optimism bias. Provided that this does not differ systematically as between administration and administrative receivership — and we have no reason for thinking that it shouldthen this ratio can nevertheless provide a meaningful way of comparing the effectiveness of the two procedures. Two sets of summary statistics for this measure of effectiveness, based respectively on total realizations (R1) and total realizations plus net trading receipts (R2), are also reported in Panel B of Table 3. For both measures, the median for our pre-Enterprise Act receivership sample is significantly smaller than for our administration sample. There is no statistically significant difference in the means.

account in cases where the business continued to operate. In most of the receivership cases, the receiver did not provide a separate trading receipt and payment account. In these cases, information on gross trading receipts and net trading receipts was identified from the receiver's general 'abstract of receipts and payments' report.

24 There is a theoretical possibility of double-counting, if operating income is used to buy capital assets which are subsequently sold. However, the insolvency practitioner's role is viewed as realizing value from existing assets, rather than restructuring the business, so such cases are likely to be rare. We did not identify any such cases in our data.

Review of Law \& Economics, (C 2012 by De Gruyter 
The Costs and Benefits of Secured Creditor Control in Bankruptcy / 119

\subsection{CosTs}

We employ two measures of the direct costs of insolvency proceedings: (i) the remuneration paid to insolvency practitioners, and (ii) total direct costs (comprising, in addition to insolvency practitioner remuneration, all of the costs associated with the realization of the assets, e.g. legal fees, estate agent fees, document fees, etc). In order to interpret the results meaningfully across the two different proceedings, we scale the costs by the estimated market value of the firm's total assets on entry into bankruptcy, taken from the Statement of Affairs. We winsorize these data at the 1\% and 99\% level. Panel B of Table 3 reports summary statistics for both remuneration and total direct costs. For both measures, both the mean and the median for our pre-Enterprise Act receivership sample are significantly smaller than for our administration sample.

\subsection{OTHER OUTCOMES}

Panel B of Table 3 also presents summary statistics on three further measures of outcomes. The creditors' recovery rate is calculated as the net difference between asset realizations plus net trading receipts (that is, REA2) minus total direct costs, as a fraction of the total face value of creditors' claims. There are no significant differences between mean recovery rates for the pre-Act receivership and administration samples, although recoveries in the post-Act receivership sample are significantly higher than for administration.

We also present descriptive statistics for two binary indicators of outcomes: the proportion of cases in which the firm continues to trade during the bankruptcy proceedings, and the proportion of cases in which a going concern sale of some or all of the firm's business - as opposed to a piecemeal sale-is achieved. In each case, the receivership and administration samples are very similar.

Table 4 explores univariate correlations between our variables of interest. Type is a dummy variable taking the value of one for administration proceedings and zero for receivership. It is modestly positively correlated with measures of realizations and of costs, providing initial support for hypotheses 1 and 2 . There is little correlation between our main variables. Few of the independent variables are correlated, implying that multicollinearity is not a concern. 
Table 4: Correlations

\begin{tabular}{|c|c|c|c|c|c|c|c|c|c|c|}
\hline Variable & REA1 & REA2 & Remu & Dir_cost & Recov & Type & \multicolumn{4}{|c|}{ Trade Outcome Duration Debt_ratio } \\
\hline REA1 & 1.000 & & & & & & & & & \\
\hline REA2 & $\begin{array}{r}0.981 \\
(0.000)\end{array}$ & 1.000 & & & & & & & & \\
\hline Remuneration & $\begin{array}{r}0.739 \\
(0.000)\end{array}$ & $\begin{array}{r}0.740 \\
(0.000)\end{array}$ & 1.000 & & & & & & & \\
\hline Total direct costs & $\begin{array}{r}0.779 \\
(0.000)\end{array}$ & $\begin{array}{r}0.777 \\
(0.000)\end{array}$ & $\begin{array}{r}0.935 \\
(0.000)\end{array}$ & 1.000 & & & & & & \\
\hline Recovery & $\begin{array}{r}0.321 \\
(0.000)\end{array}$ & $\begin{array}{r}0.348 \\
(0.000)\end{array}$ & $\begin{array}{r}-0.044 \\
(0.425)\end{array}$ & $\begin{array}{r}-0.052 \\
(0.340)\end{array}$ & 1.000 & & & & & \\
\hline Type & $\begin{array}{r}0.128 \\
(0.025)\end{array}$ & $\begin{array}{r}0.147 \\
(0.010)\end{array}$ & $\begin{array}{r}0.197 \\
(0.001)\end{array}$ & $\begin{array}{r}0.242 \\
(0.000)\end{array}$ & $\begin{array}{r}-0.007 \\
(0.910)\end{array}$ & 1.000 & & & & \\
\hline Trade & $\begin{array}{r}0.066 \\
(0.225)\end{array}$ & $\begin{array}{r}0.095 \\
(0.078)\end{array}$ & $\begin{array}{r}0.111 \\
(0.041)\end{array}$ & $\begin{array}{r}0.065 \\
(0.233)\end{array}$ & $\begin{array}{r}0.257 \\
(0.000)\end{array}$ & $\begin{array}{r}-0.069 \\
(0.232)\end{array}$ & 1.000 & & & \\
\hline Going concern & $\begin{array}{r}0.043 \\
(0.429)\end{array}$ & $\begin{array}{r}0.016 \\
(0.764)\end{array}$ & $\begin{array}{l}-0.095 \\
(0.082)\end{array}$ & $\begin{array}{r}-0.095 \\
(0.081)\end{array}$ & $\begin{array}{r}0.101 \\
(0.064)\end{array}$ & $\begin{array}{l}-0.051 \\
(0.369)\end{array}$ & $\begin{array}{r}0.012 \\
(0.821)\end{array}$ & 1.000 & & \\
\hline Duration & $\begin{array}{r}0.029 \\
(0.597)\end{array}$ & $\begin{array}{r}0.000 \\
(0.999)\end{array}$ & $\begin{array}{r}0.000 \\
(0.996)\end{array}$ & $\begin{array}{r}-0.043 \\
(0.434)\end{array}$ & $\begin{array}{r}0.011 \\
(0.843)\end{array}$ & $\begin{array}{r}-0.605 \\
(0.000)\end{array}$ & $\begin{array}{r}0.180 \\
(0.001)\end{array}$ & $\begin{array}{r}0.040 \\
(0.454)\end{array}$ & 1.000 & \\
\hline Debt_ratio & $\begin{array}{r}0.183 \\
(0.001) \\
\end{array}$ & $\begin{array}{r}0.181 \\
(0.001) \\
\end{array}$ & $\begin{array}{r}0.521 \\
(0.000) \\
\end{array}$ & $\begin{array}{r}0.556 \\
(0.000) \\
\end{array}$ & $\begin{array}{r}-0.006 \\
(0.910) \\
\end{array}$ & $\begin{array}{r}0.051 \\
(0.370) \\
\end{array}$ & $\begin{array}{r}-0.070 \\
(0.198) \\
\end{array}$ & $\begin{array}{r}-0.103 \\
(0.055) \\
\end{array}$ & $\begin{array}{r}-0.057 \\
(0.288) \\
\end{array}$ & 1.000 \\
\hline
\end{tabular}

This table reports Pearson correlations, with $p$-values reported in parentheses. REA1 is log of the asset realizations, scaled by size, and REA2 is log of asset realizations plus net trading surplus, scaled by size; Remu is log of remuneration costs, scaled by size, and Dir_costs is total direct costs, scaled by size. Recov is the net difference between asset realizations plus net trading sales, and total direct costs divided by total claims. Type takes the value of one in an administration case and zero for pre-Act receivership; Trade equals one if the firm continues trading during insolvency proceedings and zero if not; Outcome equals one if the outcome is a going concern sale and zero if not; Duration is the log of duration of the proceedings; Debt_ratio is the ratio of total claims to the estimated value of total assets.

\section{MULTIVARIATE EMPIRICAL TESTS}

This section presents empirical tests as follows. Sections 4.1 and 4.2 respectively report results regarding realizations and direct costs. We then report various robustness checks (Section 4.3), and discuss limitations and possible future research (Section 4.4).

\subsection{REALIZATIONS}

In Table 5, we report findings on the determinants of realizations in our sample cases, comparing receiverships before the Enterprise Act 2002 with administrations after the change in the law. To ensure robustness of the results, we report specifications using two different measures of the dependent

Review of Law \& Economics, ( 2012 by De Gruyter 
The Costs and Benefits of Secured Creditor Control in Bankruptcy / 121

variable. In Panel $A$, we use total asset realizations (that is, the gross proceeds of sale of the firm's assets) (REA1), and in Panel B we use total asset realizations plus net trading receipts during the bankruptcy procedure (REA2). In each case we scale the dependent variable by firm size (measured by the estimated market value on entry to bankruptcy) and subject it to a logarithmic transformation.

Table 5: Determinants of Realizations for Pre-Act Receivership and Administration

\begin{tabular}{|c|c|c|c|c|c|c|c|}
\hline & \multirow[b]{2}{*}{$\begin{array}{l}\text { Predicted } \\
\text { sign }\end{array}$} & \multicolumn{3}{|c|}{ PANEL A: REA1 } & \multicolumn{3}{|c|}{ PANEL B: REA2 } \\
\hline & & Model 1 & Model 2 & Model 3 & Model 1 & Model 2 & Model 3 \\
\hline Intercept & & $\begin{array}{l}0.943^{+* *} \\
(10.29)\end{array}$ & $\begin{array}{l}0.941^{t+*} \\
(10.28)\end{array}$ & $\begin{array}{l}0.923^{* * *} \\
(10.10)\end{array}$ & $\begin{array}{l}0.998^{*+*} \\
(10.90)\end{array}$ & $\begin{array}{l}0.996 \\
(10.90)\end{array}$ & $\begin{array}{l}0.972^{+*+*} \\
(10.70)\end{array}$ \\
\hline Type & + & $\begin{array}{l}0.033^{\circ} \\
(1.91)\end{array}$ & $\begin{array}{r}0.035^{* *} \\
(2.03)\end{array}$ & $\begin{array}{l}0.015 \\
(0.76)\end{array}$ & $\begin{array}{c}0.039^{* *} \\
(2.27)\end{array}$ & $\begin{array}{c}0.042^{* *} \\
(2.43)\end{array}$ & $\begin{array}{l}0.018 \\
(0.90)\end{array}$ \\
\hline Trade & + & $\begin{array}{c}0.033^{*} \\
(3.28)\end{array}$ & $\begin{array}{l}0.033^{* *} \\
(3.32)\end{array}$ & $\begin{array}{c}0.032^{* *} \\
(3.17)\end{array}$ & $\begin{array}{r}0.041^{*+1} \\
(4.11)\end{array}$ & $\begin{array}{r}0.042^{+* *} \\
(4.17)\end{array}$ & $\begin{array}{r}0.040^{*+1+} \\
(4.03)\end{array}$ \\
\hline Outcome & & $\begin{array}{l}0.016 \\
(1.88)\end{array}$ & $\begin{array}{l}0.016 \\
(1.86)\end{array}$ & $\begin{array}{l}0.016^{*} \\
(1.89)\end{array}$ & $\begin{array}{l}0.010 \\
(1.15)\end{array}$ & $\begin{array}{l}0.010 \\
(1.13)\end{array}$ & $\begin{array}{l}0.010 \\
(1.19)\end{array}$ \\
\hline Duration & + & $\begin{array}{r}0.030^{*} \\
(2.22)\end{array}$ & $\begin{array}{l}0.029^{* *} \\
(2.19)\end{array}$ & $\begin{array}{c}0.033^{* *} \\
(2.48)\end{array}$ & $\begin{array}{l}0.020 \\
(1.49)\end{array}$ & $\begin{array}{l}0.019 \\
(1.46)\end{array}$ & $\begin{array}{l}0.025 \\
(1.84)\end{array}$ \\
\hline Debt_ratio & & $\begin{array}{l}0.001^{* * *} \\
(11.12)\end{array}$ & $\begin{array}{l}0.001^{+1 *} \\
(11.03)\end{array}$ & $\begin{array}{l}0.001^{* * *} \\
(11.26)\end{array}$ & $\begin{array}{l}0.001^{*+*} \\
(11.11)\end{array}$ & $\begin{array}{l}0.001^{+1 * *} \\
(11.01)\end{array}$ & $\begin{array}{l}0.001^{*+*+} \\
(11.33)\end{array}$ \\
\hline Size & & $\begin{array}{r}-0.015^{+*} \\
(-4.72)\end{array}$ & $\begin{array}{r}-0.015^{+4+4} \\
(-4.38)\end{array}$ & $\begin{array}{r}-0.014^{* *} \\
(-4.30)\end{array}$ & $\begin{array}{r}-0.015^{+1 *} \\
(-4.69)\end{array}$ & $\begin{array}{r}-0.014^{+*} \\
(-4.29)\end{array}$ & $\begin{array}{r}-0.014^{+*+*} \\
(-4.22)\end{array}$ \\
\hline Oversecured & & & $\begin{array}{l}-0.011 \\
(-1.23)\end{array}$ & $\begin{array}{l}-0.035^{* *} \\
(-2.45)\end{array}$ & & $\begin{array}{l}-0.015 \\
(-1.62)\end{array}$ & $\begin{array}{r}-0.044^{+*+x} \\
(-3.06)\end{array}$ \\
\hline OversecuredType & + & & & $\begin{array}{r}0.040^{* *} \\
(2.15)\end{array}$ & & & $\begin{array}{r}0.048^{*} \\
(2.62)\end{array}$ \\
\hline Industry dummies & & Yes & Yes & Yes & Yes & Yes & Yes \\
\hline Year dummies & & Yes & Yes & Yes & Yes & Yes & Yes \\
\hline Observations & & 306 & 306 & 306 & 305 & 305 & 305 \\
\hline Adjusted R² & & 0.402 & 0.403 & 0.410 & 0.403 & 0.407 & 0.419 \\
\hline
\end{tabular}

This table compares the determinants of asset realizations for pre-insolvency act receivership and post-Act administration, and presents coefficients from regressions with the actual realizations as the dependent variables. Data are from receiverships commencing between 1 January 2001 and 14 September 2003 and administrations commencing between 15 September 2003 and 31 December 2004. We use two measures for realizations. REA1 is log of the asset realizations, scaled by size, and $R E A 2$ is log of asset realizations plus net trading surplus, scaled by size. Type takes the value of one in an administration case and zero for pre-Act receivership; Trade equals one if the firm continues trading during insolvency proceedings and zero if not; Outcome equals one if the outcome is a going concern sale and zero if not; Duration is log of the length of the proceedings; Debtratio is the ratio of total claims to the estimated value of total assets; Size is log of the estimated value of assets at the beginning of the insolvency; Oversecured equals one if the estimated value of total assets at entry to insolvency is larger than the face value of secured creditors' claims and zero if not. Industry classifications are based on 1-digit SIC codes. T-statistics are reported in parentheses below coefficient estimates. ${ }^{* \star *},{ }^{* *},{ }^{*}$ indicate two-sided statistical significance at the $0.01,0.05$, and 0.10 level respectively. 
Table 5 Panels A and B each report specifications designed to test hypotheses 1 and 1A. Type is a dummy variable taking the value of one for administration cases and zero for pre-Act receiverships. Model 1 is our basic specification, in which we include as controls a range of variables which may be expected to influence realizations, including whether the office-holder continues to trade the business or closes it down (Trade), whether a going concern sale or a breakup sale occurs (Outcome), the number of days taken to complete the proceedings (Duration), the firm's leverage, measured against the market value of its prebankruptcy assets (Debt_ratio), and firm size, also measured in terms of the market value of pre-bankruptcy assets (Size). We also include industry and year fixed effects. All the results are robust to the exclusion of the potentially endogenous control variables (Trade, Outcome, and Duration), to the exclusion of year fixed effects, and to discounting realizations at an annual rate of $5 \%$ to reflect the time value of money.

The results for Model 1 are supportive of hypothesis 1 . For both measures of the dependent variable, the coefficient for Type is positive and statistically significant (at the 5\% level for realizations including net trading receiptsPanel B-and at the 10\% level for realizations excluding trading receiptsPanel A). This indicates that realizations are higher in administration cases than in receiverships. As the dependent variables are expressed as natural logarithms, the coefficients measure the elasticity of the (scaled) realization amount with respect to explanatory variables. That is, when the explanatory variable is also a natural logarithm, the coefficient indicates the percentage change in the amount of realizations amount that is associated either with a $1 \%$ change in the explanatory variable or with the value of a dummy variable, holding all other variables constant. Thus, the coefficients for Type in Model 1 indicate that mean asset realizations and asset realizations net of trading receipts are, respectively, $3.3 \%$ and $4.1 \%$ higher in administration than receivership, when scaled for firm size.

Models 2 and 3 provide tests of hypothesis $1 \mathrm{~A}$ specifically, namely that the increase in realizations in administrations is likely to be particularly associated with cases where secured lenders are oversecured. Model 2 is identical to Model 1, but with the addition of an additional dummy variable, Oversecured, which takes the value of one if the market value of the debtor's assets on entry to bankruptcy is greater than the face value of secured debt, and zero otherwise. The coefficient for Oversecured is not statistically significant, and the coefficient for Type remains positive and statistically significant (increasing from the $10 \%$ to the $5 \%$ level in Panel A).

Model 3 is identical to Model 2, but with the addition of an interaction term, Oversecured ${ }^{*}$ Type which captures the joint effect of both being in administration

\section{Review of Law \& Economics, () 2012 by De Gruyter}


The Costs and Benefits of Secured Creditor Control in Bankruptcy / 123

rather than receivership and having oversecured lenders. The coefficient for the interaction term is positive and statistically significant at the 5\% level and the coefficient for Type is no longer statistically significant. This implies that the increase in realizations in administration captured by the positive coefficient for Type in Models 1 and 2 is actually driven by cases where the secured lenders are oversecured. The coefficient for Oversecured is negative and statistically significant in Model 3. This indicates that, over the sample as a whole, oversecured secured lenders are associated with lower realizations. However, the size of the negative coefficient is smaller than the positive coefficient on the interaction term Oversecured ${ }^{*}$ Type, implying that for firms in administration, the negative effect of being oversecured is more than cancelled out by the difference in procedure. These results are strongly supportive of hypothesis 1A. As regards economic significance, these coefficients imply that where secured lenders are oversecured, use of administration rather than receivership is associated with a $4 \%$ increase in total realizations, and a $4.8 \%$ increase in realizations net of trading receipts, both scaled for firm size. These results are robust to the exclusion of each of the independent variables, although we do not report these specifications. ${ }^{25}$

A number of the coefficients for control variables are also statistically significant. The positive coefficient for Trade in all specifications implies that, as expected, cases where the office-holder continues to trade the business are associated with higher realizations. The positive and statistically significant coefficient for Debt_ratio indicates that higher leverage is associated with greater realizations, although the relatively small size of these coefficients indicates that its economic significance is small. The coefficients for Size are negative and highly statistically significant (at the 1\% level) in all specifications, indicating that there is a scale effect in realizations, with smaller debtors yielding disproportionately larger realizations. The coefficients for Duration, which are positive, are statistically significant in Panel A (total asset realizations) but not Panel B (asset realizations plus net trading receipts). This is probably because the dependent variable in Panel $\mathrm{B}$ takes into account the trading payments associated with continued trading, which will be rising in the time spent in insolvency proceedings.

\subsection{DIRECT COSTS}

Table 6 reports results on the determinants of direct costs, once again comparing receiverships before the Enterprise Act 2002 with administrations after the change in the law. We once more report specifications based on two different

\footnotetext{
${ }^{25}$ Further specifications are available on request.
} 
measures of costs, being natural logs, scaled by firm size, of (i) the fees paid to the insolvency practitioner running the case (Remuneration), and (ii) remuneration plus any other direct costs incurred in the proceedings-for example, surveyors' fees, legal fees, marketing costs, etc (Total direct costs).

We used the same explanatory variables as in our analysis of realizations, namely a dummy for use of administration as opposed to receivership (Type), dummies for continued trading (Trade) and going concern sale (Outcome), log of time spent in proceedings (Duration), ratio of debt to market value of assets at the commencement of bankruptcy (Debt_ratio), firm size as measured by market value of assets (Size), and dummies for oversecured secured lenders (Oversecured) and an interaction term for use of administration when secured lenders are oversecured (Oversecured ${ }^{*} T y p e$ ). We also include dummies to control for industry and year fixed effects. Consistently with hypothesis 2 , and with the descriptive statistics, all specifications show that the bankruptcy procedure used makes an economically, and strongly statistically significant, difference to the ratio of costs to total value of the realizations.

Our results indicate that direct costs in administration are higher than in preAct receivership cases by a factor of between $4.7 \%$ and $5.9 \%$. Cases in which the insolvency practitioner decides to carry on trading can result in higher remuneration costs and higher total direct costs, and all of the costs are positively correlated with the length of proceedings. The negative and statistically significant coefficients for Size imply that, consistently with prior research (LoPucki and Doherty, 2006) there is a scale effect in costs in our sample. This presumably results from a fixed cost element associated with any appointment, leading to a declining costs rate (as a proportion of assets) for firms with larger assets. We find little evidence of any industry effect, or that the choice between going concern sale and piecemeal sale has costs implications. We find no evidence that having oversecured lenders makes any difference to direct costs. All the results are robust to the exclusion of the potentially endogenous control variables (Trade, Outcome, and Duration), to the exclusion of year fixed effects, and to discounting costs at an annual rate of $5 \%$ to reflect the time value of money.

As discussed, the duration of the administration cases was statutorily limited, whereas receiverships were not. This might be thought to introduce a bias against administration in the costs results. That is, the regression results suggest that receiverships are cheaper given their apparently greater duration, yet practitioners told us that much of the activity in receiverships occurs in the first few months of any event. As a cross-check against this concern, we tried two additional specifications. In the first (Model 4 in Table 6), we added an interaction term, Duration*Type, in order to determine whether the effects of

\section{Review of Law \& Economics, () 2012 by De Gruyter}


The Costs and Benefits of Secured Creditor Control in Bankruptcy / 125

duration were particularly pronounced in either proceeding, and in the second (Model 5 in Table 6), we added a nonlinear term to capture duration, Duration_Squared. In neither case were the coefficients for the additional terms statistically significant; however, the Duration coefficient remained positive and statistically significant in both specifications. This implies that the effect of duration is not an artifact of the statutory truncation of the length of administration proceedings.

Table 6: Determinants of Direct Costs for Pre-Act Receivership and Administration

\begin{tabular}{|c|c|c|c|c|c|c|c|c|c|c|c|}
\hline & Predic & Model 1 & Model 2 & Model 3 & Model 4 & Model 5 & Model 1 & Model 2 & Model 3 & Model 4 & Model 5 \\
\hline Intercept & & $\begin{array}{l}0.983^{3+1} \\
(11.81)\end{array}$ & $\begin{array}{l}0.984^{* * *} \\
(11.80)\end{array}$ & $\begin{array}{l}0.980^{*} \\
(11.68)\end{array}$ & $\begin{array}{l}0.982 \\
(10.39\end{array}$ & $\begin{array}{l}0.606 \\
(1.21)\end{array}$ & $\begin{array}{l}1.060^{\circ} \\
(13.44)\end{array}$ & $\begin{array}{l}1.060^{*+*} \\
(13.41)\end{array}$ & $\begin{array}{l}1.0499^{* \prime \prime} \\
(13.22)\end{array}$ & $\begin{array}{l}1.033^{+3} \\
(11.55)\end{array}$ & $\begin{array}{l}0.757 \\
(1.60)\end{array}$ \\
\hline Type & + & $\begin{array}{r}0.053^{\prime \prime} \\
(3.29)\end{array}$ & $\begin{array}{r}0.051^{1+*} \\
(3.21)\end{array}$ & $\begin{array}{r}0.047^{*} \\
(2.57)\end{array}$ & $\begin{array}{l}0.058 \\
(2.04)\end{array}$ & $\begin{array}{c}0.056^{\prime \prime} \\
(2.84)\end{array}$ & $\begin{array}{r}0.058^{* * *} \\
(3.87)\end{array}$ & $\begin{array}{r}0.059^{+*} \\
(3.89)\end{array}$ & $\begin{array}{r}0.047^{*} \\
(2.76)\end{array}$ & $\begin{array}{r}0.055^{*} \\
(2.06)\end{array}$ & $\begin{array}{r}0.048 \\
(2.60)\end{array}$ \\
\hline Trade & + & $\begin{array}{r}0.056 \\
(6.11)\end{array}$ & $\begin{array}{r}0.056^{-*} \\
(6.08)\end{array}$ & $\begin{array}{r}0.055^{\ldots+} \\
(6.02)\end{array}$ & $\begin{array}{r}0.060^{\circ} \\
(6.01)\end{array}$ & $\begin{array}{r}0.060^{\circ *} \\
(6.06)\end{array}$ & $\begin{array}{r}0.047^{\mathrm{*} *} \\
(5.41)\end{array}$ & $\begin{array}{r}0.047^{\text {tat }} \\
(5.41)\end{array}$ & $\begin{array}{r}0.046^{+} \\
(5.31)\end{array}$ & $\begin{array}{r}0.046 \\
(4.87)\end{array}$ & $\begin{array}{r}0.046^{+} \\
(4.91)\end{array}$ \\
\hline Outcome & & $\begin{array}{l}0.008 \\
(1.02)\end{array}$ & $\begin{array}{l}0.008 \\
(1.03)\end{array}$ & $\begin{array}{l}0.008 \\
(1.04)\end{array}$ & $\begin{array}{l}0.011 \\
(1.33)\end{array}$ & $\begin{array}{c}0.012 \\
(1.38)\end{array}$ & $\begin{array}{l}0.010 \\
(1.29)\end{array}$ & $\begin{array}{l}0.010 \\
(1.28)\end{array}$ & $\begin{array}{l}0.010 \\
(1.30)\end{array}$ & $\begin{array}{l}0.010 \\
(1.19)\end{array}$ & $\begin{array}{l}0.010 \\
(1.27)\end{array}$ \\
\hline Debt_ratio & & $\begin{array}{r}0.001^{\prime+4} \\
(8.72)\end{array}$ & $\begin{array}{r}0.001^{* *+} \\
(8.73)\end{array}$ & $\begin{array}{r}0.001^{* * *} \\
(8.72)\end{array}$ & $\begin{array}{r}0.001^{\prime \prime} \\
(8.44)\end{array}$ & $\begin{array}{r}0.001^{\prime *} \\
(8.49)\end{array}$ & $\begin{array}{r}0.001^{\prime \prime} \\
(9.86)\end{array}$ & $\begin{array}{r}0.001^{*+*} \\
(9.80)\end{array}$ & $\begin{array}{r}0.001^{+*+} \\
(9.90)\end{array}$ & $\begin{array}{r}0.001^{+} \\
(9.54)\end{array}$ & $\begin{array}{r}0.001^{+} \\
(9.60)\end{array}$ \\
\hline Size & & $\begin{array}{l}-0.035^{+\ldots+} \\
(-11.80)\end{array}$ & $\begin{array}{l}-0.036 \\
(-11.64)\end{array}$ & $\begin{array}{l}-0.036 \\
(-11.57)\end{array}$ & $\begin{array}{l}-0.036 \\
(-11.37)\end{array}$ & $\begin{array}{l}-0.036^{4} \\
(-11.35)\end{array}$ & $\begin{array}{l}-0.033^{\ldots+} \\
(-11.82)\end{array}$ & $\begin{array}{l}-0.033^{+\ldots+} \\
(-11.47)\end{array}$ & $\begin{array}{l}-0.033^{+\ldots+} \\
(-11.39)\end{array}$ & $\begin{array}{l}-0.033^{*+1} \\
(-11.09)\end{array}$ & $\begin{array}{l}-0.033^{+1+} \\
(-11.08)\end{array}$ \\
\hline Oversecured & & & $\begin{array}{l}0.005 \\
(0.62)\end{array}$ & $\begin{array}{l}0.000 \\
(0.02)\end{array}$ & $\begin{array}{l}-0.000 \\
(-0.03)\end{array}$ & $\begin{array}{l}0.002 \\
(0.11)\end{array}$ & & $\begin{array}{l}-0.003 \\
(-0.39)\end{array}$ & $\begin{array}{l}-0.016 \\
(-1.28)\end{array}$ & $\begin{array}{l}-0.021 \\
(-1.56)\end{array}$ & $\begin{array}{l}-0.019 \\
(-1.41)\end{array}$ \\
\hline Oversecured ${ }^{\star} T y p e$ & & & & $\begin{array}{l}0.008 \\
(0.47)\end{array}$ & $\begin{array}{l}0.008 \\
(0.42)\end{array}$ & $\begin{array}{l}0.006 \\
(0.33)\end{array}$ & & & $\begin{array}{l}0.021 \\
(1.33)\end{array}$ & $\begin{array}{l}0.024 \\
(1.37)\end{array}$ & $\begin{array}{l}0.022 \\
(1.30)\end{array}$ \\
\hline $\begin{array}{l}\text { Duration } \\
\text { Duration*Type }\end{array}$ & + & $\begin{array}{r}0.041^{* *} \\
(3.42)\end{array}$ & $\begin{array}{r}0.042^{* * *} \\
(3.43)\end{array}$ & $\begin{array}{r}0.042^{\prime \prime} \\
(3.46)\end{array}$ & $\begin{array}{r}0.043 \\
(3.09) \\
-0.002 \\
(-0.14)\end{array}$ & $\begin{array}{r}0.171^{+*} \\
(3.02)\end{array}$ & $\begin{array}{c}0.032 * \\
(2.79)\end{array}$ & $\begin{array}{r}0.032^{* *} \\
(2.77)\end{array}$ & $\begin{array}{c}0.034^{*} \\
(2.94)\end{array}$ & $\begin{array}{r}0.038^{+*} \\
(2.87) \\
-0.005 \\
(-0.40)\end{array}$ & $\begin{array}{c}0.133^{*} \\
(2.85)\end{array}$ \\
\hline Duration_Squared & & & & & & $\begin{array}{l}-0.011 \\
(-0.77)\end{array}$ & & & & & $\begin{array}{l}-0.008 \\
(-0.62)\end{array}$ \\
\hline dus & & Yes & Yes & Yes & Yes & Yes & Yes & Yes & Yes & Yes & Yes \\
\hline ear & & Yes & Yes & Yes & Yes & Yes & Yes & Yes & Yes & Yes & Yes \\
\hline Obsel & & 302 & 302 & 3 & 302 & 302 & 304 & 304 & 304 & 304 & 304 \\
\hline Adjusted $\mathrm{R}^{2}$ & & 0.534 & 0.533 & 0.532 & 0.532 & 0.537 & 0.553 & 0.551 & 0.552 & 0.552 & 0.553 \\
\hline
\end{tabular}

This table compares the determinants of insolvency costs for pre-insolvency act receivership and post-Act administration, and presents coefficients from regressions with insolvency costs as the dependent variables. We use two measures for insolvency costs: Remuneration and Total direct costs. Remuneration is the log of remuneration costs, scaled by size, and Total direct costs is the log of total direct costs scaled by size. Trade is a dummy set to one if the firm continues trading during insolvency proceedings; Outcome is a dummy set to one if the outcome is a going concern sale; Debt_ratio is the ratio of total debt claims to the estimated value of total assets; Size is the log of the estimated value of assets at the beginning of the insolvency; Oversecured is a dummy set to one if the estimated value of assets at entry to insolvency is larger than the face value of secured creditors' claims; Duration is the log of the length of the insolvency proceedings. Industry classifications are based on 1-digit SIC codes. T-statistics are reported in parentheses below coefficient estimates. 


\subsection{ROBUSTNESS CHECKS}

Our empirical strategy has been to compare two samples of firms in bankruptcy, taken from before and after a change in the law. A possible confounding factor is introduced by the fact that holders of floating charges created before the date of commencement of the Enterprise Act (15 September 2003) retain the right to appoint receivers after the new law came into force (see section 2.2). Thus, in a subset of cases after the change in the law-where secured lenders have pre-2003 floating charges - a lender who prior to the Act would have relied exclusively on receivership is given the option to select either receivership or administration. The available data do not permit us to determine the creation date of floating charges, so we are unable to determine the extent to which such choice was available in our sample. However, it may introduce an element of selection bias into the administration sample. Assuming secured lenders seek to maximize their expected net returns, then they may be expected to exercise any such (post-Act) choice to select the procedure most likely to maximize recoveries and minimize costs. This selection effect would, if present, tend to bias results for administration towards higher recoveries and lower costs than pre-Act receivership. In other words, it would be a bias in favor of hypothesis 1 but against hypothesis 2. Moreover, as the decision is controlled by the secured lender, we would expect such a selection bias to be most pronounced in cases where the lender is undersecured. The intuition is that where a secured lender is oversecured, they will be less concerned about the selection of a value-maximizing procedure. If such a selection effect is present in the post-Act samples, it may be expected to manifest itself in the following ways: (i) post-Act receiverships may be expected to have higher realizations and/or lower costs than pre-Act receiverships, and (ii) there may be expected to be no, or less, difference in realizations and costs between post-Act receiverships and administrations.

In order to investigate this issue, we collected data on an additional 50 receivership cases, commenced after the introduction of the Enterprise Act. After discarding cases for which data on all variables of interest were not available, this yielded a sample of 36 post-Enterprise Act receivership cases. We then ran tests similar to those reported in sections 4.1 and 4.2 investigating the determinants of realizations and costs, but instead compared first pre- with post-Act receiverships and then post-Act administrations with post-Act receiverships.

Table 7 reports findings on the determinants of realizations and costs in receiverships both before and after the Enterprise Act 2002. The same independent variables are included as in Tables 5 and 6 , save that in place of the dummy for type of bankruptcy procedure, we now include a dummy for

\section{Review of Law \& Economics, ( 2012 by De Gruyter}


The Costs and Benefits of Secured Creditor Control in Bankruptcy / 127

procedures commencing post- the introduction of the new law (Post). Whilst the coefficients for most of the same explanatory variables are statistically significant as in Tables 5 and 6, Post is not statistically significant in any specification. We thus find no evidence that realization values are greater, or costs smaller, in post-Act receiverships. This is contrary to what we would expect were lenders using their influence to select receivership after the Act in cases where this would maximize their recoveries. Moreover, the coefficient for the dummy Oversecured is negative in respect of total realizations and realizations plus net trading receipts, but the coefficient of the interaction term on oversecured and post-Act is not significant. This implies that receivers generate fewer realizations when they are appointed by an oversecured lender, and that this effect is not measurably different between the pre-Act and post-Act samples.

Table 8 reports the results of regressions investigating the determinants of realizations and costs in receiverships and administrations commenced after the Enterprise Act 2002. Because the choice of procedure may be endogenous to the expected realizations and costs, and to the level of secured debt, we use a two-stage treatment effects regression. The first (treatment) stage is a probit regression where the dependent variable is the choice of bankruptcy procedure, a dummy taking the value one for administration and zero for receivership (Panel A). We include firm size, age, debt ratio and the proportion of secured debt as explanatory variables. Of these, only the coefficients for firm age and proportion of secured debt are statistically significant, indicating that older firms are more likely to go into administration, and firms with higher proportions of secured debt are more likely to go into receivership.

The second stage regression (Panel B) includes the full range of explanatory variables discussed above. The coefficients for type of bankruptcy procedure (Type) are significant where the dependent variable is costs, but not where it is realizations. Thus, controlling for potential selection effects in the postEnterprise Act sample, we do not find any evidence that administration is associated with higher recoveries than receivership. We do, however, find robust evidence that it is associated with higher costs. 
Table 7: Determinants of Asset Realization and Costs for Pre-Act Receivership and Post-Act Receivership

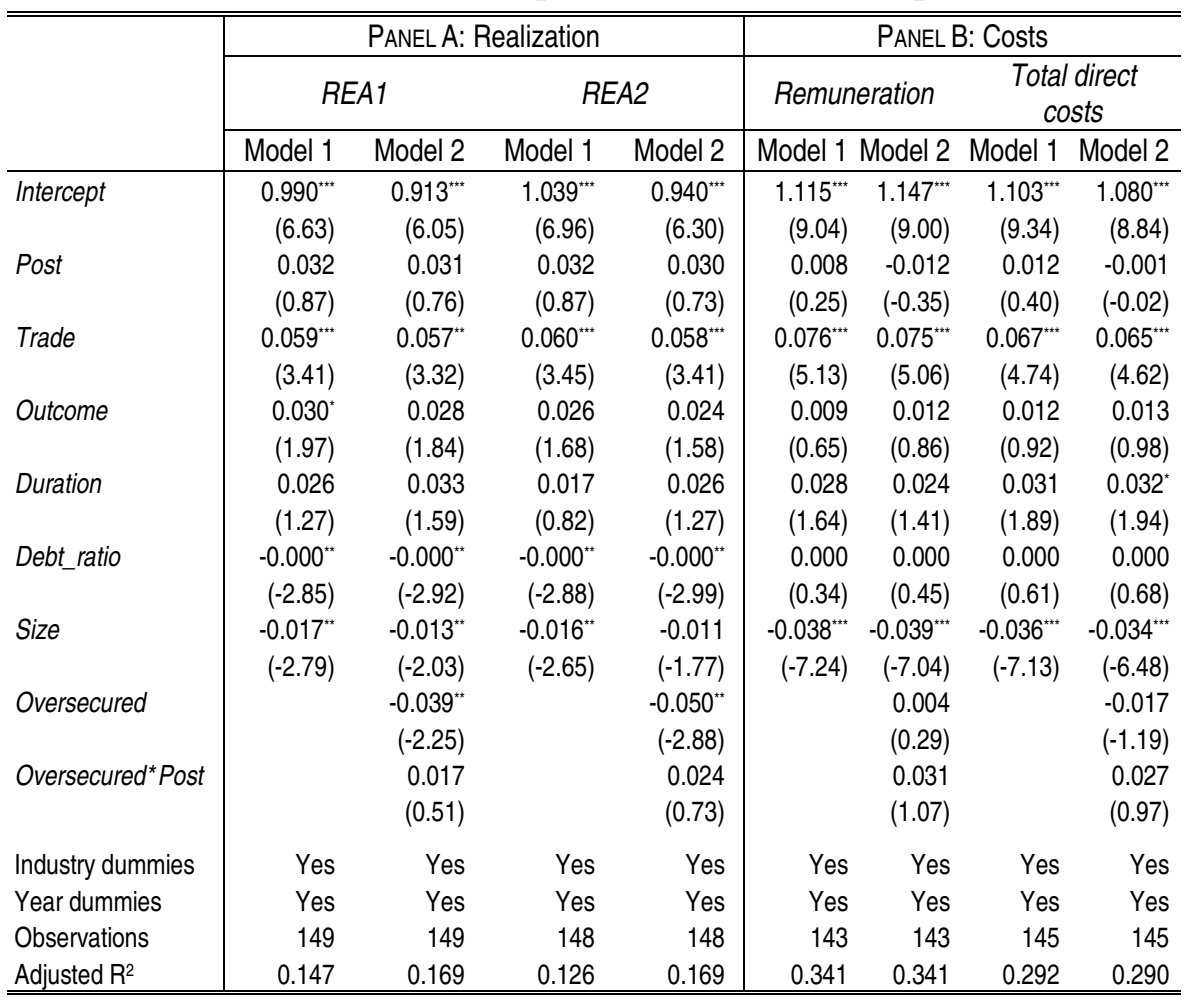

This table compares the determinants of asset realizations and insolvency costs for pre-insolvency act receivership and post-Act receivership, and presents coefficients from regressions with realization costs and insolvency costs as the dependent variables. REA1 is log of the asset realizations, scaled by size, and REA2 is log of asset realizations plus net trading surplus, scaled by size. We use three measures for insolvency costs: Remuneration, Total direct costs and Duration. Remuneration is log of remuneration costs, scaled by size, and Total direct costs is total direct costs, scaled by size. Post is a dummy set to one for post-Act receivership and zero for pre-Act receivership; Trade is a dummy set to one if the firm continues trading during insolvency proceedings; Outcome is a dummy set to one if the outcome is a going concern sale; Duration is the log of the length of the proceedings; Debt_ratio is the ratio of total debt claims to the estimated value of total assets; Size is the log of the estimated value of assets at the beginning of the insolvency; Oversecured is a dummy set to one if the estimated value of total assets at entry to insolvency is larger than the face value of secured creditors' claims. Industry classifications are based on 1-digit SIC codes. T-statistics are reported in parentheses below coefficient estimates.

Review of Law \& Economics, (C) 2012 by De Gruyter 
The Costs and Benefits of Secured Creditor Control in Bankruptcy / 129

Table 8: Determinants of Asset Realization and Cost for Administration and Post-Act Receivership (Treatment Effects)

\begin{tabular}{|c|c|c|c|c|c|c|c|c|c|c|}
\hline \multicolumn{2}{|c|}{$\begin{array}{l}\text { PANEL A: } \\
\text { Probit regression } \\
\text { for first step }\end{array}$} & \multicolumn{9}{|c|}{ PANEL B: Treatment effects regressions } \\
\hline & \multirow{3}{*}{\begin{tabular}{|c|} 
Type \\
Model1
\end{tabular}} & & \multicolumn{4}{|c|}{ Realization } & \multicolumn{4}{|c|}{ Costs } \\
\hline & & & \multicolumn{2}{|c|}{ REA1 } & \multicolumn{2}{|c|}{ REA2 } & \multicolumn{2}{|c|}{ Remuneration } & \multicolumn{2}{|c|}{ Total direct costs } \\
\hline & & & Model1 & Model2 & Model1 & Model2 & Model1 & Model2 & Model1 & Model2 \\
\hline Intercept & \begin{tabular}{|c|}
$2.537^{\circ}$ \\
$(2.46)$
\end{tabular} & Intercept & $\begin{array}{r}0.989^{* \prime} \\
(7.12)\end{array}$ & $\begin{array}{c}0.992 " * \\
(7.11)\end{array}$ & $\begin{array}{r}1.029^{+3+4} \\
(7.36)\end{array}$ & $\begin{array}{r}1.031^{* *} \\
(7.34)\end{array}$ & $\begin{array}{l}0.923^{\prime *} \\
(10.68)\end{array}$ & $\begin{array}{l}0.923^{* *} \\
(10.51)\end{array}$ & $\begin{array}{l}1.035^{* *} \\
(12.31)\end{array}$ & $\begin{array}{l}1.032+" \\
(12.07)\end{array}$ \\
\hline Size & $\begin{array}{l}-0.165 \\
(-1.86)\end{array}$ & Type & $\begin{array}{l}0.016 \\
(0.43)\end{array}$ & $\begin{array}{l}0.023 \\
(0.55)\end{array}$ & $\begin{array}{l}0.014 \\
(0.37)\end{array}$ & $\begin{array}{l}0.021 \\
(0.51)\end{array}$ & $\begin{array}{r}0.104^{\prime \prime *} \\
(3.95)\end{array}$ & $\begin{array}{r}0.103^{* *} \\
(3.56)\end{array}$ & $\begin{array}{c}0.074^{*} \\
(3.02)\end{array}$ & $\begin{array}{r}0.071^{\prime \prime} \\
(2.58)\end{array}$ \\
\hline Age & $\begin{array}{l}0.378^{*} \\
(2.63)\end{array}$ & Trade & $\begin{array}{l}0.020 \\
(1.46)\end{array}$ & $\begin{array}{l}0.020 \\
(1.47)\end{array}$ & $\begin{array}{l}0.031^{*} \\
(2.24)\end{array}$ & $\begin{array}{l}0.031^{*} \\
(2.25)\end{array}$ & $\begin{array}{r}0.047^{* *+} \\
(5.42)\end{array}$ & $\begin{array}{r}0.047^{+* *+} \\
(5.41)\end{array}$ & $\begin{array}{r}0.034^{+*+1} \\
(3.94)\end{array}$ & $\begin{array}{r}0.034^{++*} \\
(3.93)\end{array}$ \\
\hline Debt_ratio & $\begin{array}{l}-0.002 \\
(-1.42)\end{array}$ & Outcome & $\begin{array}{l}0.030^{*} \\
(2.46)\end{array}$ & $\begin{array}{l}0.030^{*} \\
(2.47)\end{array}$ & $\begin{array}{l}0.025^{*} \\
(2.07)\end{array}$ & $\begin{array}{l}0.026^{*} \\
(2.08)\end{array}$ & $\begin{array}{l}0.006 \\
(0.79)\end{array}$ & $\begin{array}{l}0.006 \\
(0.79)\end{array}$ & $\begin{array}{l}0.001 \\
(0.10)\end{array}$ & $\begin{array}{l}0.001 \\
(0.09)\end{array}$ \\
\hline \multirow[t]{6}{*}{$\begin{array}{l}\text { Prop_ } \\
\text { secured }\end{array}$} & $\begin{array}{r}-1.859 \\
(-4.50)\end{array}$ & Duration & $\begin{array}{l}0.048^{*} \\
(2.37)\end{array}$ & $\begin{array}{l}0.047^{\circ} \\
(2.26)\end{array}$ & $\begin{array}{l}0.042 \\
(2.07)\end{array}$ & $\begin{array}{l}0.041^{*} \\
(1.97)\end{array}$ & $\begin{array}{r}0.039^{* *} \\
(3.14)\end{array}$ & $\begin{array}{r}0.039^{*} \\
(3.08)\end{array}$ & $\begin{array}{l}0.029^{\circ} \\
(2.30)\end{array}$ & $\begin{array}{l}0.030^{\circ} \\
(2.33)\end{array}$ \\
\hline & & Debt_ratio & $\begin{array}{l}0.000^{*} \\
(2.11)\end{array}$ & $\begin{array}{l}0.000^{*} \\
(2.13)\end{array}$ & $\begin{array}{l}0.000^{*} \\
(2.00)\end{array}$ & $\begin{array}{l}0.000^{*} \\
(2.02)\end{array}$ & $\begin{array}{r}0.001^{* *} \\
(9.75)\end{array}$ & $\begin{array}{r}0.001^{* *} \\
(9.73)\end{array}$ & $\begin{array}{l}0.001^{1+*} \\
(11.26)\end{array}$ & $\begin{array}{l}0.001^{+\ldots} \\
(11.21)\end{array}$ \\
\hline & & Size & $\begin{array}{r}-0.026^{*} \\
(-6.09)\end{array}$ & $\begin{array}{r}-0.026^{\prime \prime} \\
(-5.73)\end{array}$ & $\begin{array}{r}-0.026^{\prime+1} \\
(-6.10)\end{array}$ & $\begin{array}{r}-0.026^{*} \\
(-5.73)\end{array}$ & $\begin{array}{l}-0.0322^{\prime *} \\
(-10.29)\end{array}$ & $\begin{array}{l}-0.032+\cdots \\
(-10.03)\end{array}$ & $\begin{array}{l}-0.030 \\
(-10.49)\end{array}$ & $\begin{array}{l}-0.030 \\
(-10.15)\end{array}$ \\
\hline & & Oversecured & & $\begin{array}{l}0.011 \\
(0.36)\end{array}$ & & $\begin{array}{l}0.007 \\
(0.21)\end{array}$ & & $\begin{array}{l}0.001 \\
(0.05)\end{array}$ & & $\begin{array}{l}-0.005 \\
(-0.23)\end{array}$ \\
\hline & & Oversecured ${ }^{*}$ Pos: & & $\begin{array}{l}-0.017 \\
(-0.52)\end{array}$ & & $\begin{array}{l}-0.012 \\
(-0.37)\end{array}$ & & $\begin{array}{l}-0.000 \\
(-0.00)\end{array}$ & & $\begin{array}{l}0.007 \\
(0.34)\end{array}$ \\
\hline & & Lambda & $\begin{array}{l}-0.002 \\
(-0.08)\end{array}$ & $\begin{array}{l}-0.000 \\
(-0.02)\end{array}$ & $\begin{array}{l}-0.000 \\
(-0.00)\end{array}$ & $\begin{array}{l}-0.000 \\
(-0.01)\end{array}$ & $\begin{array}{r}-0.051^{* * *} \\
(-3.40)\end{array}$ & $\begin{array}{r}-0.051^{*} \\
(-2.96)\end{array}$ & $\begin{array}{l}-0.029^{*} \\
(-2.03)\end{array}$ & $\begin{array}{l}-0.030 \\
(-1.78)\end{array}$ \\
\hline \multirow[t]{2}{*}{ Ind. dummies } & Yes & Industrydummies & Yes & Yes & Yes & Yes & Yes & Yes & Yes & Yes \\
\hline & & Year dummies & Yes & Yes & Yes & Yes & Yes & Yes & Yes & Yes \\
\hline & 233 & Observations & 232 & 232 & 232 & 232 & 230 & 230 & 230 & 230 \\
\hline Adjusted R² & 0.245 & Wald Chi & $75.10^{\text {tot* }}$ & 75.176 & $72.56^{* * *}$ & $72.21^{*+*}$ & $425.1^{\prime * *}$ & $370.1^{* * *}$ & $468.1^{1+* t}$ & $418.3^{\text {tit }}$ \\
\hline
\end{tabular}

This table presents coefficients from a treatment effects regression with Type as a procedure dummy. The first step for treatment is the Probit regression reported in Panel A and the results for the treatment effects regression are in Panel B. Size is log of the value of the firm's assets at the start of bankruptcy; Age is the age of the firm on entering bankruptcy; Debt_ratio is the ratio of total claims to the value of assets; Prop_secured is the proportion of secured debt over total claims. $R E A 1$ is $\log$ of asset realizations; REA2 is log of asset realizations plus net trading surplus; Remuneration is log of remuneration costs; and Total direct costs is total direct costs, all scaled by size. Type is one for administration and zero for post-Act receivership; Trade is one if firm continues trading in bankruptcy and zero otherwise; Outcome is one if there is a going concern sale and zero otherwise; Duration is log of the length of the proceeding; Oversecured is one if total asset value exceeds the face value of secured creditors' claims and zero otherwise. Lambda is the inverseMills ratio. T-statistics are reported in parentheses below coefficient estimates. 
The results of these tests incorporating the post-Act receivership sample show that our finding of increased costs associated with administration as compared to receivership, which supports hypothesis 2 , is highly robust. This is true both for a comparison between pre-Act receivership and post-Act administration (Table 6), as well as between post-Act administrations and receiverships (Table 8 ) in a treatment effects specification. Moreover, the costs of receiverships have not increased significantly since the Enterprise Act (Table 7), further evidencing that the increase is associated with the use of administration, rather than with any other developments that may have influenced insolvency procedures more generally.

The findings as regards realizations are less clear-cut. Our comparison of pre-Act receivership with post-Act administration (Table 5) suggested that administration was associated with higher realizations, especially where the secured lender is oversecured, supporting hypotheses 1 and 1A. However, one interpretation of the absence of a significant difference in realizations between post-Act receiverships and administrations in Table 8 is that secured lenders are selecting the procedure so as to maximize realizations. This consequently raises a suggestion of selection bias in the post-Act administration sample, which would bias the sample in favor of hypothesis 1 and $1 \mathrm{~A}$ in the tests conducted in Table 5. Yet if this were the case, we would expect the bias-and consequent uplift in recoveries for post-Act administration as against pre-Act receivershipto be strongest in cases where the secured creditor is undersecured, as here they will have the strongest incentive to select a procedure which will maximize their recoveries. However, Table 5 reports that the increase in realizations is driven entirely by cases in which the lender is oversecured. In such cases the lender should be indifferent in selection as between administration and receivership. The size of our post-Act receivership sample is small, and it may simply be that any realizations effect is so small that we do not have the statistical power to capture it in our treatment effects specification.

Moreover, we find no evidence that realizations have increased in post-Act receiverships as compared to receiverships commenced prior to the Enterprise Act (Table 7). We would expect to see such an increase if, after the Act, lender selection was biasing procedure choice towards those expected to yield higher realizations. This tends to contradict the inference of selection bias, and indirectly supports hypothesis 1 . Moreover, Table 7 provides further support for hypothesis $1 \mathrm{~A}$ in reporting a negative association between oversecured lenders and realizations in receiverships both before and after the change in the law. This implies that oversecured lenders were associated with lower returns in receiverships before the change in the law, and that this effect is still present in post-Act receiverships.

Review of Law \& Economics, (C 2012 by De Gruyter 
The Costs and Benefits of Secured Creditor Control in Bankruptcy / 131

\subsection{LIMITATIONS AND FUTURE RESEARCH}

There is necessarily a considerable amount of uncertainty involved in the application of a new bankruptcy procedure. Empirical results from the early years of the Chapter 11 procedure in the US found that the (then) new law had given debtors a great deal of power, and creditors correspondingly less (LoPucki, 1983). However, the law's effect has tended to become diluted with time as participants respond by 'contracting around' the law (Baird and Rasmussen, 2002; Skeel, 2004). A similar process may well occur in the UK. It is therefore too soon to say whether the changes documented in our results will persist, or whether they may simply be disequilibrium effects resulting from transition. Further research conducted after the Enterprise Act regime has had time to 'bed down' would shed light on this issue.

However, a study of the immediate impact of a change in the law is nevertheless valuable because it offers a more direct comparison of the old and new regimes than a study with an intervening gap of several years. The wider the time difference between the two samples, the greater the possibility that a temporal bias may be introduced, if unobserved time-variant effects impact upon the costs and recoveries in bankruptcy proceedings.

\section{CONCLUSIONS AND IMPLICATIONS}

Recent changes in UK bankruptcy law have made it possible to examine empirically the costs and benefits of different degrees of secured creditor control in bankruptcy. The move in 2003 from receivership to administration may be seen in stylized terms as effecting a shift in control rights from secured to unsecured creditors in bankruptcy proceedings. To investigate the impact of this change, we present findings from a hand-coded dataset of 340 bankruptcy cases, which comprises the largest sample of bankruptcy realizations and costs yet reported. ${ }^{26}$

We find that cases conducted under the new administration procedure are much quicker than receiverships, taking on average a little over half the time. This is entirely consistent with predictions, given the statutory time limit for administration proceedings.

Our strongest finding is that the direct costs associated with bankruptcy are greater in administration than in receivership, controlling for a range of other explanatory variables. This result is robust to the possibility of bias in the selection of bankruptcy procedure in the post-Enterprise Act environment, introduced by the retention of a power to appoint a receiver by lenders with

\footnotetext{
${ }^{26}$ Lubben (2008) reports findings on bankruptcy costs for a much larger sample, but does not investigate realizations.
} 
floating charges granted before 15 September 2003, to control for which we used a treatment effects specification to compare the costs associated with post-Act receiverships and administrations. These findings are consistent with hypothesis 2, which asserts that the greater use of legal mechanisms of accountability in administration-through the administrators' fiduciary duties to all creditors, and the need to take a creditor vote in many cases-will introduce concomitant costs not present in receivership.

At the same time, we find evidence consistent with hypothesis 1 , namely that administration cases are associated with higher gross recoveries than were receiverships. Moreover, this difference is entirely driven by cases where the secured lender is oversecured, in accordance with hypothesis 1A. This is consistent with the intuition that greater accountability to unsecured creditors encourages administrators to act more effectively to generate recoveries in cases where, as fiduciaries for the senior claimant, they would have lacked sufficient incentives under receivership. However, this finding is less robust than our findings regarding costs, and we cannot exclude the possibility that it is an artifact of secured lenders' ability to select between administration and receivership where they have a floating charge pre-dating the change in the law.

Thus, whilst gross realizations in administration are higher, so too are costs, and it appears that the net effect on creditors therefore is equivocal. Moreover, administrations do not result in any significantly greater incidence of continued trading or going concern sales than did receiverships, indicating that the new procedure is not preserving any more employment.

The shift from secured to unsecured creditor control has plausibly increased the power of the insolvency practitioner-the agent-as against the creditors-the principals. The very high costs awarded under administration imply that, in many cases, the professional running the case is effectively the residual claimant. In turn, this provides an alternative, and less benign, explanation for the increase in gross recoveries under the new regime: it is because, with weak monitoring from unsecured creditors, insolvency practitioners have themselves become the residual claimant in UK bankruptcies: they have a strong incentive to maximize the recoveries that will go to pay fee income.

There is no appreciable difference in decisions concerning the allocation of the firm's assets (that is, continuation or closure) following the change in the law. This tends to contradict the idea that administrators are systematically able to identify more efficient buyers than receivers. Consequently, the increase in gross realizations is perhaps most plausibly interpreted as a distributional matter, with administrators appointed in the presence of oversecured lenders working harder to extract more of the surplus from asset buyers than do their colleagues appointed as receivers. However, the increase in direct costs implies

\section{Review of Law \& Economics, (C) 2012 by De Gruyter}


The Costs and Benefits of Secured Creditor Control in Bankruptcy / 133

a greater deadweight loss. Thus, we tentatively conclude that the welfare interpretation of our results may be negative.

Our results also have more general implications for the debate about bankruptcy contracting and the desirability of secured creditor control. The change in UK bankruptcy governance, in essence, involves a crossing of the central fault line of corporate governance: a shift in control from a concentrated investor to many dispersed investors. With concentrated investor control, the main governance problem is how to prevent them from extracting rents from other investors. With control rights in the hands of dispersed investors, the problem is rather how to prevent those managing the firm from extracting rents. No clear consensus has emerged as to which of these is preferable. Our results imply that concentrated creditor governance in bankruptcy, in the form of strong control rights allocated to a single concentrated lender, does on average at least as good a job at preserving jobs and generating recoveries for creditors as does a relatively sophisticated legal procedure designed to allocate control to the residual claimant.

\section{References}

Adler, B. 1997. "A Theory of Corporate Insolvency," 72 NYU Law Review 343-382.

Aghion, P., O. Hart, and J. Moore. 1992. "The Economics of Bankruptcy Reform," 8 Journal of Law, Economics and Organization 523-546.

Armour, J. 2006. "Should we Redistribute in Insolvency?" in J. Getzler and J. Payne, eds. Company Charges: Spectrum and Beyond. Oxford: Oxford University Press, 189-226. B.R. Cheffins, and D.A. Skeel, Jr. 2002. "Corporate Ownership Structure and the Evolution of Bankruptcy Law: Lessons from the UK," 55 Vanderbilt Law Review 1699-1785. and S. Frisby. 2001. "Rethinking Receivership," 21 Oxford Journal of Legal Studies 73-102. and R.J. Mokal. 2005. "Reforming the Governance of Corporate Rescue: The Enterprise Act 2002," [2005] Lloyds' Maritime and Commercial Law Quarterly 32-68.

Ayotte, K., and E. Morrison. 2008. "Creditor Control and Conflict in Chapter 11," Columbia Law and Economics Research Paper, No. 321.

Baird, D.G., and R. Rasmussen. 2002. "The End of Bankruptcy," 55 Stanford Law Review 751-789. and 2006. "Private Debt and the Missing Lever of Corporate Governance," 154 University of Pennsylvania Law Review 101-143.

Benveniste, I. 1986. "Receivers: Double Agents or Surrogate Liquidators?” 16 Accounting and Business Research 245.

Bris, A., I. Welch, and N. Zhu. 2006. "The Costs of Bankruptcy: Chapter 7 Liquidation vs. Chapter 11 Reorganization," 61 Journal of Finance 1253-1303. 
Citron, D., M. Wright, F. Rippington, and R. Ball. 2004. "Bankruptcy Costs, Leverage and Multiple Secured Creditors: The Case of MBOs," working paper, Cass Business School/University of Nottingham CMBOR, December 2004.

Companies House. 2005. Liquidation and Insolvency (Cardiff: Companies House), available online at http://www.companieshouse.gov.uk/about/pdf/gbw1.pdf.

Cork Committee. 1982. Insolvency Law and Practice. London: HMSO.

Djankov, S., O. Hart, and C. McLiesh. 2008. "Debt Enforcement Around the World," 116 Journal of Political Economy 1105-1149.

Ferran, E. 2008. Corporate Finance Law, 2nd ed. Oxford: Oxford University Press.

Finch, V. 1999. "Security, Insolvency and Risk: Who Pays the Price?" 62 Modern Law Review 633.

. 2002. Corporate Insolvency Law: Principles and Policies. Cambridge: Cambridge University Press.

Franks, J., and O. Sussman. 2000. "The Cycle of Corporate Distress, Rescue and Dissolution: A Study of Small and Medium Size UK Companies," working paper, 19 April 2000.

and 2005. "Financial Distress and Bank Restructuring of Small to Medium Size UK Companies," 9 Review of Finance 65-96.

Frisby, S. 2004. "In Search of a Rescue Culture-The Enterprise Act 2002," 67 Modern Law Review 247.

2006. "Report on Insolvency Outcomes," working paper, University of Nottingham, June 2006.

Gennaioli, N., and S. Rossi. 2008. "Optimal Resolutions of Financial Distress by Contract," working paper, CREI Universitat Pompeu Fabra and Stockholm School of Economics.

Hart, O. 1995. Firms, Contracts and Financial Structure. Oxford: Clarendon Press.

Insolvency Service. 2001. Insolvency-A Second Chance, Cm 5234. London: DTI.

Jackson, T.H. 1986. The Logic and Limits of Bankruptcy Law. Cambridge, MA: Harvard University Press.

La Porta, R., F. Lopes-de-Silanes, A. Shleifer, and R. Vishny. 1998. "Law and Finance," 106 Journal of Political Economy 1113-1155.

Lawless, R.M., and S.P. Ferris. 1997. "Professional Fees and Other Direct Costs in Chapter 7 Business Liquidations," 75 Washington Univ. Law Quarterly 1207-1236. and 2000. "The Expenses of Financial Distress: Direct Costs in Chapter 11 Bankruptcies," 61 University of Pittsburgh Law Review 629-669.

LoPucki, L.M. 1983. "The Debtor in Full Control—Systems Failure Under Chapter 11 of the Bankruptcy Code?" 57 American Bankruptcy Law Journal 247. . 1999. "Contract Bankruptcy: A Reply to Alan Schwartz," 109 Yale Law Journal 317-342.

and J.W. Doherty. 2004. "The Determinants of Professional Fees in Large Bankruptcy Reorganization Cases," 1 Journal of Empirical Legal Studies 111-141. and 2006. "The Determinants of Professional Fees in Large Bankruptcy Reorganization Cases Revisited," UCLA School of Law, Law \& Economics Research Paper No. 06-16.

Review of Law \& Economics, () 2012 by De Gruyter 
The Costs and Benefits of Secured Creditor Control in Bankruptcy / 135

Lubben, S.J. 2008. "Corporate Reorganization and Professional Fees," 82 American Bankrupty Law Journal 77-140.

Mokal, R.J. 2004. "Administration and Administrative Receivership: An Analysis," 57 Current Legal Problems 355-392.

Office of Fair Trading (OFT). 2010. The Market for Corporate Insolvency Practitioners: A Market Study, OFT 1245. London: Office of Fair Trading. Available online at http://www.oft.gov.uk/shared_oft/reports/Insolvency/oft1245.

Picker, R. 1992. "Security Interests, Misbehavior, and Common Pools," 59 University of Chicago Law Review 645-679.

Rasmussen, R. 1992. "Debtor's Choice: A Menu Approach to Corporate Bankruptcy," 71 Texas Law Review 51-121.

Safavian, M., and S. Sharma. 2007. "When Do Creditor Rights Work?" 35 Journal of Comparative Economics 484-508.

Schwartz, A. 1994. "The Absolute Priority Rule and the Firm's Investment Policy," 72 Washington University Law Quarterly 1213-1229.

1997. "Contracting About Bankruptcy," 13 Journal of Law, Economics and Organization 127-143.

. 1998. "A Contract Theory Approach to Business Bankruptcy," 107 Yale Law Journal 1807-1851.

Scott, R.E. 1986. "A Relational Theory of Secured Financing," 86 Columbia Law Review 901-970.

Shleifer, A., and R.W. Vishny. 1992. "Liquidation Value and Debt Capacity: A Market Equilibrium Approach," 47 Journal of Finance 1343-1366. and 1997. "A Survey of Corporate Governance," 52 Journal of Finance 737-783.

Skeel, D.A., Jr. 2004. "The Past, Present and Future of Debtor-in-Possession Financing," 25 Cardozo Law Review 1905-1934.

Thorburn, K. 2000. "Bankruptcy Auctions: Costs, Debt Recovery, and Firm Survival," 58 Journal of Financial Economics 337-368.

Triantis, G., and R. Daniels. 1995. "The Role of Debt in Interactive Corporate Governance," 83 California Law Review 1073-1113.

Webb, D.C. 1990. "An Economic Evaluation of Insolvency Procedures in the United Kingdom: Does the 1986 Insolvency Act Satisfy the Creditors' Bargain?” 43 Oxford Economic Papers 139-157.

Westbrook, J.L. 2004. "The Control of Wealth in Bankruptcy," 82 Texas Law Review 795-862.

White, M.J. 1996. "The Costs of Corporate Bankruptcy: A US-European Comparison," in J.S. Bhandari and L.A. Weiss, eds. Corporate Bankrupty: Legal and Economic Perspectives. Cambridge: Cambridge University Press, 467-500. 